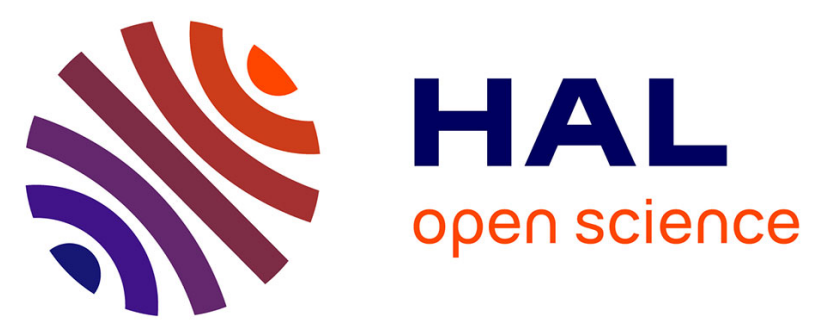

\title{
Experimental and kinetic modeling study of n-hexane oxidation. Detection of complex low-temperature products using high-resolution mass spectrometry
}

Nesrine Belhadj, Maxence Lailliau, Roland Benoit, Philippe Dagaut

\section{- To cite this version:}

Nesrine Belhadj, Maxence Lailliau, Roland Benoit, Philippe Dagaut. Experimental and kinetic modeling study of n-hexane oxidation. Detection of complex low-temperature products using high-resolution mass spectrometry. Combustion and Flame, 2021, 233, pp.111581. 10.1016/j.combustflame.2021.111581 . hal-03291957

\section{HAL Id: hal-03291957 \\ https://hal.science/hal-03291957}

Submitted on 20 Jul 2021

HAL is a multi-disciplinary open access archive for the deposit and dissemination of scientific research documents, whether they are published or not. The documents may come from teaching and research institutions in France or abroad, or from public or private research centers.
L'archive ouverte pluridisciplinaire HAL, est destinée au dépôt et à la diffusion de documents scientifiques de niveau recherche, publiés ou non, émanant des établissements d'enseignement et de recherche français ou étrangers, des laboratoires publics ou privés.

$$
\text { Copyright }
$$




\title{
Experimental and kinetic modeling study of n-hexane oxidation. Detection of complex low-temperature products using high-resolution mass spectrometry.
}

\author{
Nesrine Belhadj ${ }^{1,2}$, Maxence Lailliau ${ }^{1,2}$, Roland Benoit ${ }^{1}$, Philippe Dagaut ${ }^{1}{ }^{1}$ * \\ ${ }^{1}$ CNRS-INSIS, ICARE, 1C avenue de la Recherche Scientifique, 45071 Orléans cedex 2, France \\ ${ }^{2}$ Université d'Orléans, rue de Chartres, 45100 Orléans, France \\ *Corresponding author: \\ Philippe Dagaut \\ CNRS-ICARE, Institut de Combustion, Aérothermique, Réactivité et Environnement \\ 1C Avenue de la Recherche Scientifique \\ 45071 Orléans Cedex 2, France \\ Tel: +33(0)238255466 \\ dagaut@cnrs-orleans.fr
}

\begin{abstract}
This study concerns the oxidation of $n$-hexane. It was conducted in continuous flow fused-silica jet-stirred reactor (JSR) at $10 \mathrm{~atm}$ and an equivalence ratio of 0.5 . n-Hexane initial concentrations were (i) $2500 \mathrm{ppm}$ with a mean residence time of $1.5 \mathrm{~s}$ and (ii) $1000 \mathrm{ppm}$ with a mean residence time of $0.7 \mathrm{~s}$; we operated in the cool-flame regime for temperatures ranging from 540 to $720 \mathrm{~K}$ and 530 to $800 \mathrm{~K}$, respectively. Products were analyzed and quantified in the gas phase using gas chromatography (with flame ionization, thermal conductivity, and quadrupole mass spectrometry) and Fourier transform infrared spectrometry. Products of low-temperature oxidation were sampled in the JSR and trapped in acetonitrile for characterization using an Orbitrap Q-Exactive ${ }^{\circledR}$. Flow injection analyses (FIA) and ultra-high pressure liquid chromatography (UHPLC) coupled with atmospheric pressure chemical ionization (APCI +/- modes)- high resolution mass spectrometry (HRMS) analyses were used to characterize hydroperoxides $\left(\mathrm{C}_{6} \mathrm{H}_{14} \mathrm{O}_{2}\right)$, keto-hydroperoxides $\left(\mathrm{C}_{6} \mathrm{H}_{12} \mathrm{O}_{3}, \mathrm{C}_{3} \mathrm{H}_{6} \mathrm{O}_{3}, \mathrm{C}_{4} \mathrm{H}_{8} \mathrm{O}_{3}\right.$, and $\left.\mathrm{C}_{5} \mathrm{H}_{10} \mathrm{O}_{3}\right)$, cyclic ethers $\left(\mathrm{C}_{6} \mathrm{H}_{12} \mathrm{O}\right)$, carboxylic acids $\left(\mathrm{C}_{2}\right.$ to $\left.\mathrm{C}_{6}\right)$, ketones $\left(\mathrm{C}_{3}\right.$ to $\left.\mathrm{C}_{6}\right)$, diones $\left(\mathrm{C}_{6} \mathrm{H}_{10} \mathrm{O}_{2}\right)$, unsaturated ketones $\left(\mathrm{C}_{6} \mathrm{H}_{10} \mathrm{O}\right.$ and $\left.\mathrm{C}_{6} \mathrm{H}_{8} \mathrm{O}\right)$, unsaturated diones $\left(\mathrm{C}_{6} \mathrm{H}_{8} \mathrm{O}_{2}\right)$, and highly oxygenated molecules $\left(\mathrm{C}_{6} \mathrm{H}_{12} \mathrm{O}_{4-8}\right)$ produced by addition of three and four oxygen molecules on fuel's radicals. To confirm the presence of hydroxyl or hydroperoxyl groups in the oxidation products we used $\mathrm{H} / \mathrm{D}$ exchange with $\mathrm{D}_{2} \mathrm{O}$. 2,4-Dinitrophenylhydrazine (2,4-DNPH) derivatization was used to characterize and confirm the presence of different carbonyls which can be formed during the low temperature oxidation of $n$-hexane. An available kinetic reaction mechanism including $3^{\text {rd }} \mathrm{O}_{2}$ addition on fuel's radicals was used to simulate the formation of the presently detected keto-hydroperoxides (KHP) and highly oxygenated molecules (HOMs).
\end{abstract}

Keywords: n-hexane, cool flame, keto-hydroperoxides, highly oxygenated molecules, Orbitrap, jet-stirred reactor

\section{Introduction}

Normal and branched alkanes are major constituents of commercial liquid fuels [1-3]. Recently, n-alkanes such as $n$-hexane have been used as additives to conventional fuels for improving the combustion properties and efficiency of diesel engines [4-6]. The ignition, combustion, and oxidation of primary reference fuels has already been the topic of many studies conducted over a wide range of conditions. Techniques such as shock tubes, rapid compression machines, burners, combustion chambers, reactors, and piston engines have been used. In comparison, the oxidation of intermediate length alkanes such as n-hexane has received less attention. Previous studies have focused mainly on the high-temperature oxidation of n-hexane, while few studies have been conducted under lowtemperature oxidation regime. Burcat et al. have reported ignition delay times for $\mathrm{n}$-hexane- $\mathrm{O}_{2}$-Ar mixtures in a shock tube over a range of temperatures $(1020-1725 \mathrm{~K})$ and pressures (1-7 atm) [7]. Zhukov et al. have determined ignition delay times for n-hexane over an higher range of pressures ( 11-244 atm) and still high-temperatures (822$1380 \mathrm{~K})$ [8]. Mével et al. [9] have studied the atmospheric pressure oxidation of n-hexane in a flow reactor at low temperatures (450-1000 K). More recently, Wang et al. [10] have reported a study of the atmospheric pressure oxidation of the five hexane isomers at low-temperature (550-1000 K) in a JSR. They have measured intermediates and products concentrations by both gas chromatography and synchrotron-based mass spectrometry [11]. Cyclic ether isomers mainly formed in the NTC region have been identified and quantified. At the same time, Zhang et al. [12] have reported an extensive set of experimental data for $n$-hexane oxidation: ignition delay times of stoichiometric $\mathrm{n}$-hexane mixtures in synthetic air $\left(21 \% \mathrm{O}_{2}\right.$ and $79 \%$ diluent $)$ determined using a rapid compression machine and a shock tube (627-1365 K, 15-32 bar), and speciation in a JSR (530-1160 K, 10 atm). These data 
were used by Zhang et al. [13] to update a detailed kinetic reaction mechanism for n-hexane oxidation. Later, Wang and Sarathy [14] extended the model of Zhang et al. [13] by introducing the third addition of molecular oxygen on fuel's radicals. Nevertheless, under piston engines operating conditions, i.e., low-temperature and high-pressure conditions, there is a lack of data for the complex pool of intermediates governing ignition and pollutants formation [15]. Relatively few studies have reported the formation of elusive low-temperature oxidation products, e.g. fuel's hydroperoxides (ROOH), keto-hydroperoxides (KHPs) [16-24], and highly oxygenated molecules (HOMs). Such species were recently observed in oxidation experiments involving a JSR and Molecular beam- synchrotronvacuum UV-Photoionization-TOF MS and/or HESI- or APCI-Orbitrap ${ }^{\circledR}$ (heated electrospray ionization, atmospheric pressure chemical ionization), conducted for a range of fuels [15, 25-34]. Besides the autoxidation route considered in combustion yielding ketohydroperoxides, i.e., fuel $+\mathrm{X}^{\cdot}\left({ }^{\circ} \mathrm{OH}, \mathrm{H}^{*}, \mathrm{O}^{\circ}, \mathrm{HO}_{2}{ }^{\circ}, \mathrm{O}_{2} \ldots\right) \rightarrow \mathrm{R}^{\circ}+\mathrm{XH}$; $\mathrm{R}+\mathrm{O}_{2} \rightarrow \mathrm{ROO}^{\circ} \rightarrow{ }^{\circ} \mathrm{QOOH}\left(\mathrm{H}\right.$-shift); ${ }^{\circ} \mathrm{QOOH}+\mathrm{O}_{2} \rightarrow{ }^{\circ} \mathrm{OOQOOH} \rightarrow \mathrm{HOOQ}=\mathrm{O}+{ }^{\circ} \mathrm{OH}$, a pathway involving peroxy radicals' self-reaction, considered in atmospheric chemistry but neglected in combustion, can play a role, i.e., $2 \mathrm{ROO}^{\circ} \rightarrow \mathrm{ROOOOR} \rightarrow 2 \mathrm{RO}^{\circ}+\mathrm{O}_{2}$; $\mathrm{RO}^{\circ} \rightarrow{ }^{\circ} \mathrm{QOH}\left(\mathrm{H}\right.$-shift); ${ }^{\circ} \mathrm{QOH}+\mathrm{O}_{2} \rightarrow{ }^{\circ} \mathrm{OOQOH} \rightarrow \mathrm{OQ}^{\prime} \mathrm{OH}+{ }^{\circ} \mathrm{OH}$.

HOMs formation is usually ignored in combustion while they represent major intermediates for the formation of secondary organic aerosols in the atmosphere [35]. The separation of KHPs formed by oxidation of large hydrocarbons has been pursued using chromatography and detection by UV absorption or mass spectrometry [1624], but until recently the authors faced technical limitations. With recent powerful analytical techniques such as ultra-high pressure liquid chromatography (UHPLC), and high-resolution mass spectrometry (Orbitrap®) one can improve the characterization of complex low-temperature oxidation products $[29,31-34,36]$.

As part of ongoing efforts for increasing our knowledge of fuels' cool-flame oxidation mechanisms, a series of experiments were conducted in a JSR. They aim to better characterizing the low temperature oxidation products of n-hexane. To this end, gas chromatography (GC), Fourier Transform Infrared spectrometry (FTIR), liquid chromatography (UHPLC) and Orbitrap were used. Hydroperoxides, unsaturated hydroperoxides, ketohydroperoxides, diones, ketones, aldehydes, carboxylic acids, cyclic ethers, and extensively oxygenated molecules, formed via multiple $\mathrm{O}_{2}$ additions on fuel's radicals and $\mathrm{H}$-shifts, were detected using soft chemical ionization (APCI +/-) and high-resolution mass spectrometry (HRMS). A chemical kinetic scheme involving HOMs formation routes [14] was tested against the present data.

\section{Experimental}

\subsection{Experiments in a JSR}

We conducted experiments in a JSR described earlier [37] and used in previous works addressing the kinetics of oxidation of gas and liquid fuels, e.g., [38-40]. The JSR is located inside a temperature-controlled oven (ca. 1.5 $\mathrm{kW}$ ), which maintains the reactor at the desired working temperature, surrounded by insulating ceramic wool and a pressure-resistant stainless-steel housing. The temperature of the JSR was varied stepwise. As before [41] nhexane ( $>99 \%$ pure from Sigma Aldrich) was atomized and vaporized using an in-house setup. The fuel- $\mathrm{N}_{2}$ and $\mathrm{O}_{2^{-}}$ $\mathrm{N}_{2}$ mixtures flowed separately to the four JSR injectors (nozzles of $1 \mathrm{~mm} \mathrm{I.D.)} \mathrm{to} \mathrm{avoid} \mathrm{premature} \mathrm{fuel} \mathrm{oxidation.}$ $\mathrm{N}_{2}$ and $\mathrm{O}_{2}$ flow rates were controlled by mass flow meters (Brooks). n-Hexane was pumped by means of an HPLC pump (Shimadzu LC10 AD VP) equipped with an online degasser (Shimadzu DGU-20 A3). Table 1 gives the experimental conditions. To better probe the formation of highly oxygenated products, besides operating with 1000 ppm of n-hexane, as in our earlier works, we performed experiments with higher fuel concentrations (2500 ppm).

Table 1. Experimental conditions.

\begin{tabular}{|c|c|c|}
\cline { 2 - 3 } \multicolumn{1}{c|}{} & Condition 1 & Condition 2 \\
\hline $\begin{array}{c}\text { Initial fuel, } \mathrm{O}_{2} \text {, and } \mathrm{N}_{2} \\
\text { concentration }\end{array}$ & $2500 \mathrm{ppm}, 4.75 \%, 95 \%$ & $1000 \mathrm{ppm}, 1.9 \%, 98 \%$ \\
\hline Equivalence ratio $(\varphi)$ & 0.5 & 0.5 \\
\hline Residence time & $1.5 \mathrm{~s}$ & $0.7 \mathrm{~s}$ \\
\hline Pressure & $10 \mathrm{~atm}$ & $10 \mathrm{~atm}$ \\
\hline Temperature range & 540 to $720 \mathrm{~K}$ & 530 to $800 \mathrm{~K}$ \\
\hline
\end{tabular}

Pt-Pt/Rh-10\% thermocouples (wires of $100 \mu \mathrm{m}$ insulated inside a thin-wall fused-silica housing) were used to check thermal homogeneity throughout the vertical axis of the reactor. Gradients of $<1 \mathrm{~K} / \mathrm{cm}$ were measured. A movable low-pressure fused-silica sonic probe was used to take samples for analyses. Products were analyzed in 
the gas phase by GC (with flame ionization-FID, thermal conductivity-TCD, and quadrupole mass spectrometry) and online FTIR. External calibration was used for quantifications.

Cool-flame products, e.g., hydroperoxides, cyclic ethers, keto-hydroperoxides (KHPs), di-keto-hydroperoxides, keto-di-hydroperoxides, and other highly oxygenated products were also measured. Gas samples exiting the sonic probe were directed to an amber glass vial filled with acetonitrile for $75 \mathrm{~min}\left(0^{\circ} \mathrm{C}, 25 \mathrm{~mL}\right)$. The sample solutions were stored at $-15^{\circ} \mathrm{C}$ in a freezer for future chemical analyses.

\subsection{Orbitrap analyses}

We followed the procedure described in recent publications [29, 32, 42-45]. Oxidized products were analyzed by gas chromatography and reverse-phase liquid chromatography (Table 2). HRMS analyses were conducted by flow injection (FIA). The liquid samples were injected into the APCI chamber of an Orbitrap® Q-Exactive mass spectrometer (resolution $\mathrm{m} / \Delta \mathrm{m}=140,000$ at $\mathrm{m} / z$ 200; mass accuracy $<1 \mathrm{ppm}$ RMS). The instrument allows for 'exact mass' measurements, not attainable with other techniques such as Q-ToF or time-of-flight MS (mass resolution ca. 4000). Also, UHPLC-HRMS (Thermo Scientific) was used. Soft ionization of samples was done using an Ion Max® atmospheric pressure chemical ionization (APCI) in positive and negative modes (Table 3). This technique is suitable for the detection of moderate polarity compounds, such as the products of lowtemperature oxidation of n-hexane. MS-MS analyses were conducted at higher energy collisional dissociation (HCD) of $10 \mathrm{eV}$ in order to determine the chemical structure of products based on their fragments.

Table 2. Gas-phase chromatography and reverse-phase liquid chromatography analyses conditions.

\begin{tabular}{|c|c|c|}
\hline & GC & UHPLC \\
\hline Analytical column & $\begin{array}{c}\text { Coupling of two capillary columns: } \\
\text { CP-Sil 5CB }(1.2 \mu \mathrm{m}, 0.32 \mathrm{~mm}, 25 \mathrm{~m}) \text { and } \\
\text { DB-1 }(3 \mu \mathrm{m}, 0.53 \mathrm{~mm}, 30 \mathrm{~m})\end{array}$ & $\begin{array}{c}\mathrm{C}_{18}(\text { Phenomenex } \\
\text { Luna, } 1.6 \mu \mathrm{m}, 100 \AA \text {, } \\
100 \mathrm{x} 2.1 \mathrm{~mm})\end{array}$ \\
\hline Oven temperature & $\begin{array}{l}\text { Constant at } 35^{\circ} \mathrm{C} \text { for } 30 \mathrm{~min} \text {, increasing by } \\
1^{\circ} \mathrm{C} / \mathrm{min} \text { until } 60^{\circ} \mathrm{C} \text {, increased by } 10^{\circ} \mathrm{C} / \mathrm{min} \\
\text { until } 200^{\circ} \mathrm{C} \text {. keep } 200^{\circ} \mathrm{C} \text { for } 1 \mathrm{~min} \text {. }\end{array}$ & $40^{\circ} \mathrm{C}$ \\
\hline $\begin{array}{l}\text { Carrier gas } \\
\text { mobile phase }\end{array}$ & $\begin{array}{l}\text { (1) Helium and (2) nitrogen } \\
\text { Flow rate (1) } 1.5 \mathrm{ml} / \mathrm{min} \text { and (2) } 15 \mathrm{~mL} / \mathrm{min}\end{array}$ & $\begin{array}{c}\text { Water/Acetonitrile } \\
\text { Elution gradient: } 3 \text { to } \\
100 \% \text { ACN. } \\
\text { Flow rate } 250 \mu 1 / \mathrm{min}\end{array}$ \\
\hline Analysis duration & (1) $70 \mathrm{~min}$ and (2) $1.5 \mathrm{~min}$ & $18 \mathrm{~min}$ \\
\hline Detector & (1) FID, MS (quadrupole), (2) TCD & HRMS (Orbitrap) \\
\hline
\end{tabular}

Table 3. APCI settings during FIA and UHPLC-MS analyses

\begin{tabular}{|c|c|c|}
\cline { 2 - 3 } \multicolumn{1}{c|}{} & FIA & UHPLC \\
\hline $\begin{array}{c}\text { Syringe or mobile phase } \\
\text { flow rate }(\mu \mathrm{l} / \mathrm{min})\end{array}$ & 3 to 5 & 250 \\
\hline Sheath gas flow $(\mathrm{a} . \mathrm{u})$ & 10 & 50 \\
\hline Auxiliary gas flow $(\mathrm{a} . \mathrm{u})$ & 1 & 10 \\
\hline Sweep gas flow $(\mathrm{a} . \mathrm{u})$ & 0 & 0 \\
\hline Capillary temperature $\left({ }^{\circ} \mathrm{C}\right)$ & 150 & 150 \\
\hline Vaporizer temperature $\left({ }^{\circ} \mathrm{C}\right)$ & 100 & 150 \\
\hline Corona discharge current $(\mu \mathrm{A})$ & 4 to 5 & 4 to 5 \\
\hline Spray voltage $(\mathrm{kV})$ & 4.2 & 4.2 \\
\hline
\end{tabular}

To verify the presence of $-\mathrm{OOH}$ and $-\mathrm{OH}$ groups in the oxidized products, as previously $[28,29,32]$, we used the fast $\mathrm{OH} / \mathrm{OD}$ exchange. To this end, $300 \mu \mathrm{L}$ of $\mathrm{D}_{2} \mathrm{O}(99.98 \%$, Sigma-Aldrich) were introduced into $1 \mathrm{~mL}$ of oxidation samples (n-Hexane $2500 \mathrm{ppm}, 600 \mathrm{~K}$ and $10 \mathrm{~atm}$ ). We let reaction proceed for 20 min before analyses in FIA, UHPLC coupled with Orbitrap mass spectrometer using APCI (+/-) modes. A 2,4-DNPH derivatization was used in order to confirm the presence of carbonyl (ketone and aldehyde) function by formation of 
DNPHydrazone derivatives (Fig. 1). The detailed mechanism is presented in Supplementary Material (Fig. S1). 20 $\mu \mathrm{L}$ of a diluted $\mathrm{H}_{3} \mathrm{PO}_{4}$ solution $(50 \mu \mathrm{L}$ of acid in $1 \mathrm{~mL}$ of $\mathrm{ACN})$ and $100 \mu$ of a saturated solution of 2,4-DNPH (2 $\mathrm{g}$ in $100 \mathrm{ml}$ of $\mathrm{ACN})$ were added to $1 \mathrm{ml}$ of n-hexane oxidized sample (600K). Negative mode APCI was used to ionize DNPHydrazone derivatives.

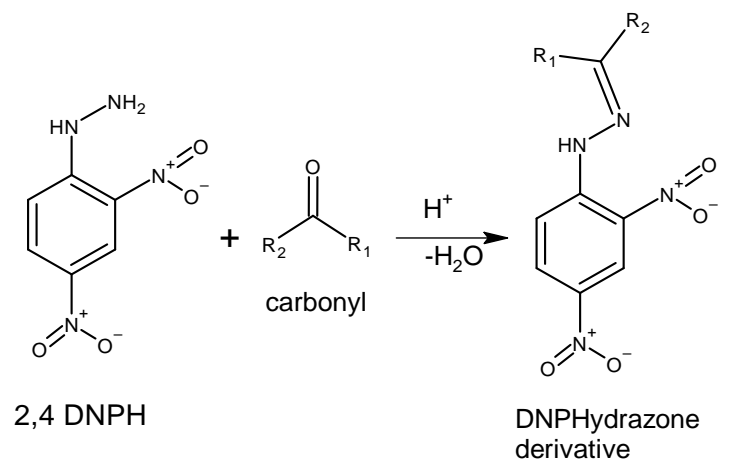

Fig. 1. Reaction of derivatization of carbonyl compounds with 2,4-DNPH.

\section{Modeling}

Simulations were conducted using PSR [46] from the Chemkin II package [47]. Third $\mathrm{O}_{2}$ addition reactions were presented in the recent kinetic reaction mechanism proposed by Wang and Sarathy [14]. Low- and hightemperature chemistry are implemented in that scheme which involves 1188 species for 4959 reactions in total. The simulations showed that in the low-temperature oxidation region, $\mathrm{n}$-hexane mainly reacts via $\mathrm{H}$-atom abstraction by hydroxyl radicals coming from the decomposition of the $\mathrm{KHP}^{2,4}$ and $\mathrm{KHP}^{3,5}$ (Table 4). A shift in temperature was observed of all concentration profiles between the modeling and the experiments. The model predicts n-hexane oxidation starts $\sim 40 \mathrm{~K}$ lower than in the experiments. In order to verify the validity of the present data, we repeated the experiments used to validate that model and found good agreement (Fig. 2) between three sets of experimental data obtained over a period of 6 years and using different JSR.
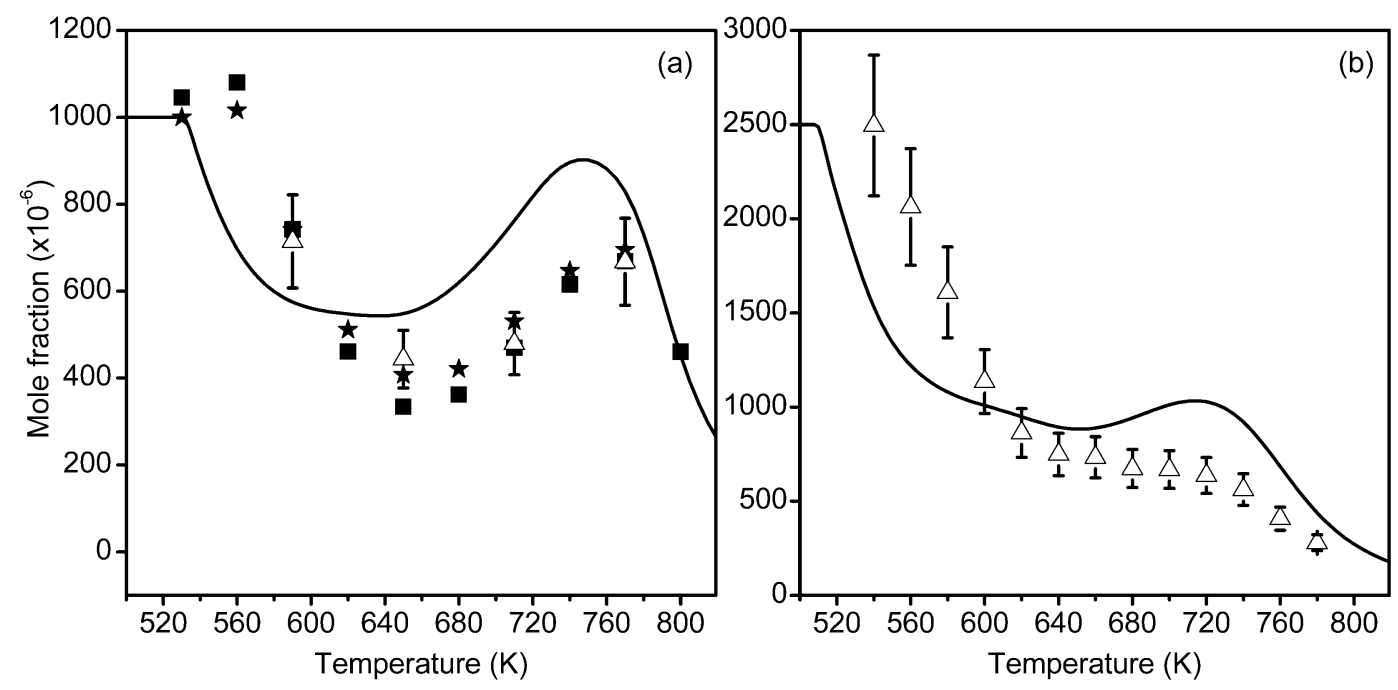

Fig. 2. Fuel profile for the oxidation of (a) $1000 \mathrm{ppm}$ initial of $n$-hexane at a pressure of $10 \mathrm{~atm},(\varphi=0.5$, residence time of $0.7 \mathrm{~s}$ ); other species profiles are presented in Figure S2 (Supplementary Material). (b) $2500 \mathrm{ppm}$ of $n$-hexane $(\varphi=0.5$, residence time of $1.5 \mathrm{~s})$. Open triangles are the present experiments, squares are the data from Zhang et al. [12], stars are unpublished data from our laboratory and the lines represent the modeling results using the mechanism proposed in [14]. 
Table 4. Structure of fuel's radicals, hydroperoxides and KHPs obtained by oxidation of n-hexane.

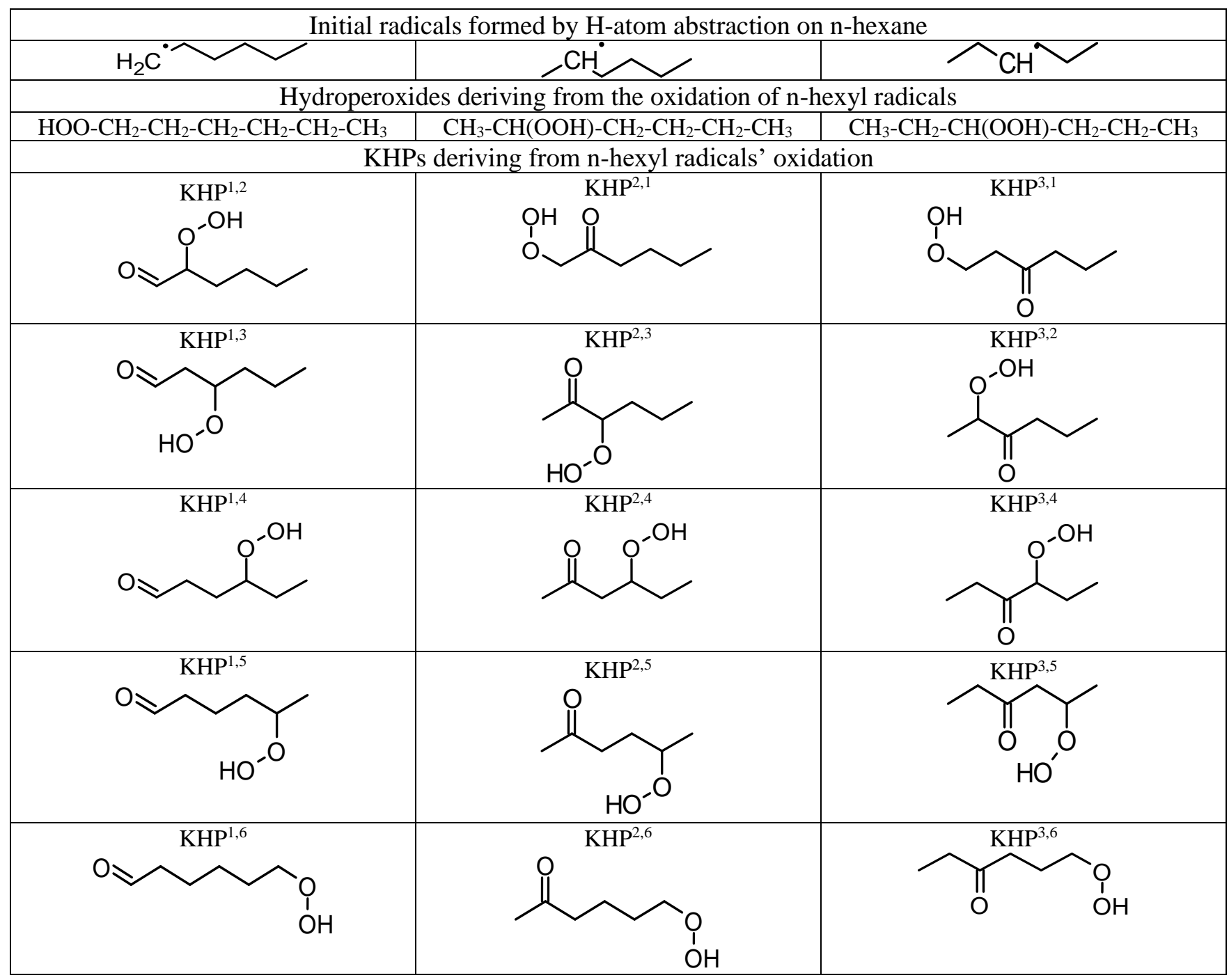

For temperature under $\sim 900 \mathrm{~K}$, the three hexyl radicals get peroxidized by reaction with $\mathrm{O}_{2}$. Three alkyl hydroperoxides can be produced after $\mathrm{H}$-atom abstraction (Table 4). Internal $\mathrm{H}$-shift in alkylperoxy radicals yields an alkyl hydroperoxyl radical. After a second addition of molecular oxygen followed by internal $\mathrm{H}$-shift and decomposition, up to 15 keto-hydroperoxides can be produced (Table 4). The literature model considered here [14] includes the $3^{\text {rd }} \mathrm{O}_{2}$ addition pathway yielding highly oxygenated products.

\section{Results and discussion}

n-Hexane oxidation was conducted in a JSR at $10 \mathrm{~atm}$ (Table 1). It yielded a wide range of products. Figure 3 presents a comparison of the present data obtained for the oxidation of $2500 \mathrm{ppm}$ of n-hexane (see Table 1) and simulations. We can notice that the kinetic modeling fails to represent the production of some chemical species. For example, an overestimation of the formation of formic acid and an underestimation of acetic acid, methanol, and ethanol is noticeable. Underpredictions could be due to the absence of some reaction pathways in the kinetic model. The over-prediction of $\mathrm{HCOOH}$, which at $600 \mathrm{~K}$, is mainly produced via the oxidation of formaldehyde by $\mathrm{OH}^{*}$ yielding $\mathrm{HOCH}_{2} \mathrm{O}^{*}$, which in turn produces $72 \%$ of formic acid by decomposition, could be due to the use of inappropriate kinetics in the model. In the kinetic model, acetic acid formation proceeds through the decomposition of 4-hydroperoxyhexan-2-one (65\%) and 3-hydroperoxyhexanal (35\%). Possibly, additional pathways are required to increase acetic acid formation, or the rate constants used in the kinetic mechanism are too slow. In the kinetic model, at $600 \mathrm{~K}$, methanol is mainly formed via three channels: self-reaction of $\mathrm{CH}_{3} \mathrm{OO}{ }^{*}(34 \%)$, $\mathrm{H}$-atom abstraction by $\mathrm{CH}_{3} \mathrm{O}^{*}$ on formaldehyde (32\%), and reaction of $\mathrm{CH}_{3} \mathrm{OO}^{*}$ with $\mathrm{OH}^{*}(20 \%)$. At $600 \mathrm{~K}$, the formation of ethanol is mainly due to $\mathrm{H}$-atom abstraction by ethoxy radicals on methylhydroperoxy radicals (66\%) and hydrogen peroxide $(24 \%)$. The inclusion of other reactions of this type could increase ethanol production. 
Figures 2 and 3 show that the kinetic model overestimates n-hexane oxidation rate below 620K. HRMS analyses allowed to observe many oxygenated products: $\mathrm{C}_{6} \mathrm{H}_{12} \mathrm{O}_{\mathrm{x}}(\mathrm{x}=1-7), \mathrm{C}_{6} \mathrm{H}_{10} \mathrm{O}_{\mathrm{x}}(\mathrm{x}=1-6), \mathrm{C}_{6} \mathrm{H}_{8} \mathrm{O}_{\mathrm{x}}(\mathrm{x}=1-6), \mathrm{C}_{6} \mathrm{H}_{6} \mathrm{O}_{\mathrm{x}}(\mathrm{x}=1-$ 6), $\mathrm{C}_{6} \mathrm{H}_{4} \mathrm{O}_{\mathrm{x}}(\mathrm{x}=3-5), \mathrm{C}_{\mathrm{n}} \mathrm{H}_{2 \mathrm{n}}(\mathrm{n}=4-6), \mathrm{C}_{\mathrm{n}} \mathrm{H}_{2 \mathrm{n}-2}(\mathrm{n}=4-6), \mathrm{C}_{\mathrm{n}} \mathrm{H}_{2 \mathrm{n}} \mathrm{O}(\mathrm{n}=3-6), \mathrm{C}_{\mathrm{n}} \mathrm{H}_{2 \mathrm{n}-2} \mathrm{O}(\mathrm{n}=3-6), \mathrm{C}_{\mathrm{n}} \mathrm{H}_{2 \mathrm{n}-4} \mathrm{O} \quad(\mathrm{n}=3-6)$, $\mathrm{C}_{\mathrm{n}} \mathrm{H}_{2 \mathrm{n}+2} \mathrm{O}_{2}(\mathrm{n}=6), \mathrm{C}_{\mathrm{n}} \mathrm{H}_{2 \mathrm{n}} \mathrm{O}_{2}(\mathrm{n}=2-6), \mathrm{C}_{\mathrm{n}} \mathrm{H}_{2 \mathrm{n}-2} \mathrm{O}_{2}(\mathrm{n}=3-6), \mathrm{C}_{\mathrm{n}} \mathrm{H}_{2 \mathrm{n}-4} \mathrm{O}_{2}(\mathrm{n}=3-6)$, and $\mathrm{C}_{\mathrm{n}} \mathrm{H}_{2 \mathrm{n}} \mathrm{O}_{3}(\mathrm{n}=1-6)$.
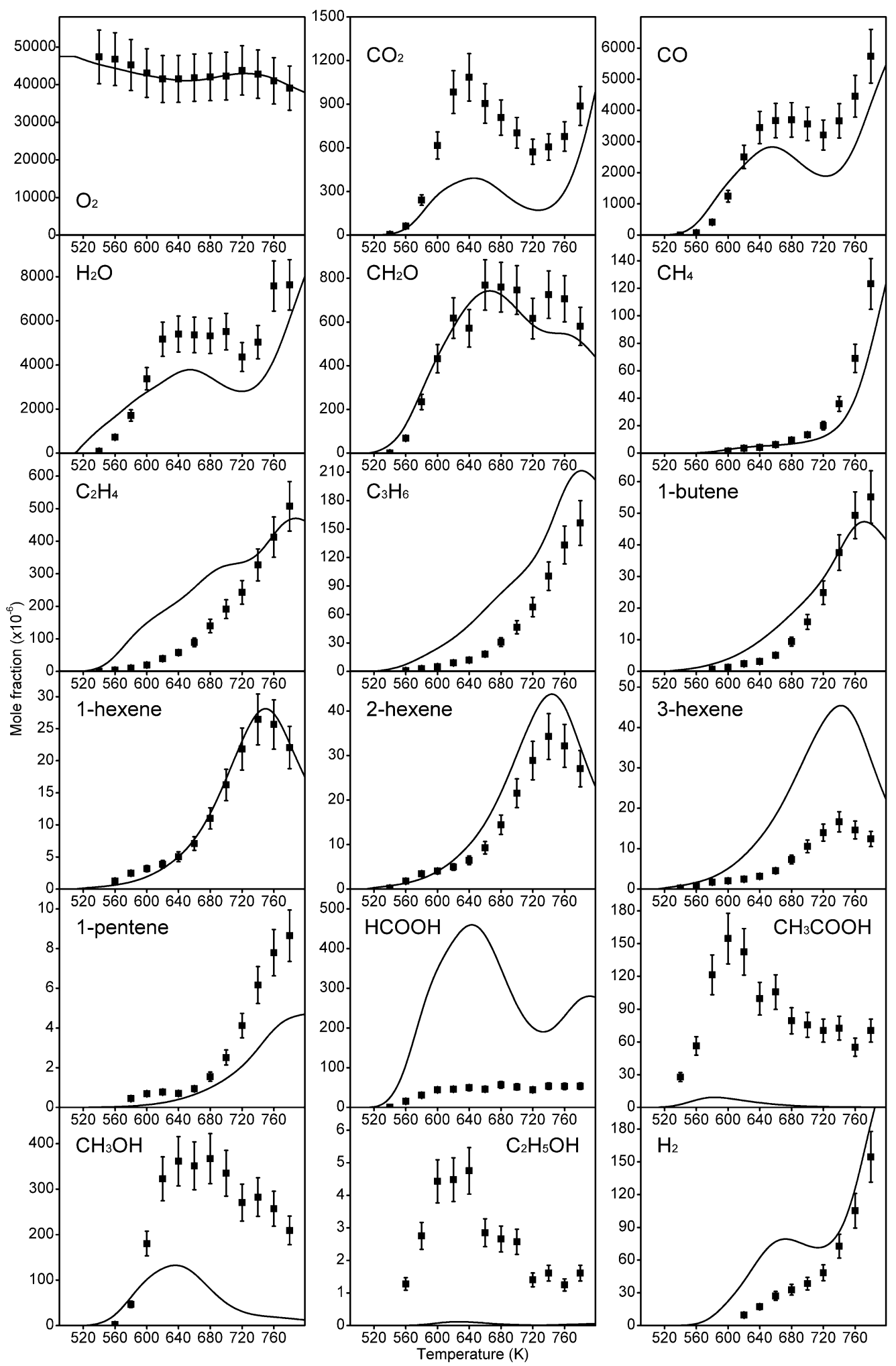

Fig. 3. Oxidation of $2500 \mathrm{ppm}$ of $\mathrm{n}$-hexane in a JSR ( $10 \mathrm{~atm}, \varphi=0.5$, residence time of $1.5 \mathrm{~s}$ ). Data obtained by GC-FID-TCD and FTIR (symbols) are compared to simulations using the model proposed earlier [14]. Results for the fuel are presented in Fig. $2 b$.

The present study indicated that besides keto-hydroperoxides, more oxygenated products are formed via multiple additions of $\mathrm{O}_{2}$ on the fuel's radicals $(\mathrm{R})$ and $\mathrm{H}$-shifts (Scheme 1). 


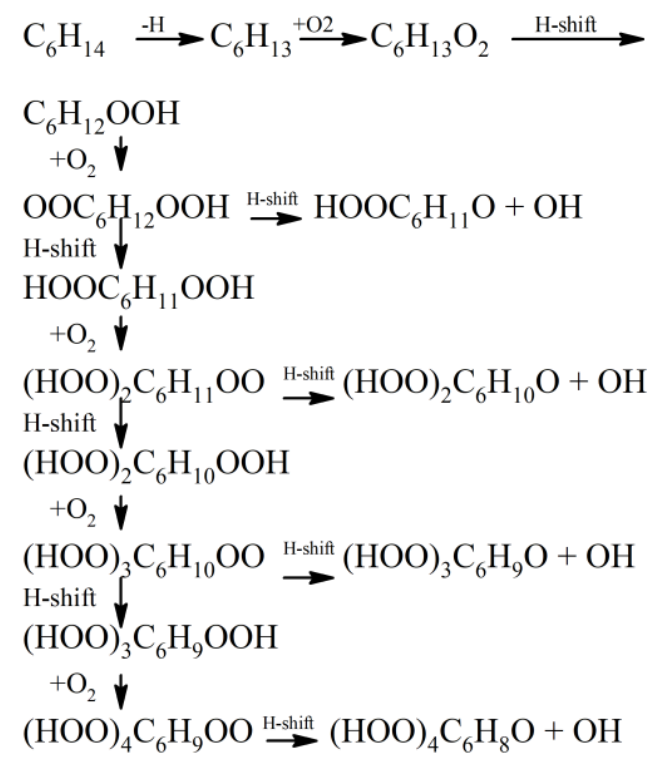

Scheme 1. Autoxidation pathways to ketohydroperoxides and HOMs after 4 molecular oxygen additions and multiple H-shifts.

In this study, we observed the products of second to 4 th $\mathrm{O}_{2}$ addition on the radicals from the fuel. The results presented in the next paragraphs confirm the extended oxidation pathways proposed earlier to rationalize experimental observations made in a JSR with molecular beam-time of flight mass spectrometry-synchrotron vacuum ultraviolet photoionization [15, 28] and JSR-Orbitrap experiments [29, 32-34]. After the formation of peroxy radicals $\left(\mathrm{RO}_{2}\right)$, other oxygenated species are produced, such as alkyl-hydroperoxides: $\mathrm{RO}_{2}+\mathrm{R}{ }^{\prime} \mathrm{H} \rightarrow \mathrm{ROOH}$ $+\mathrm{R}^{\prime}, \mathrm{RO}_{2}+\mathrm{HO}_{2} \rightarrow \mathrm{ROOH}+\mathrm{O}_{2}$.

ROOH formation was detected here (Tables 4 and 5). Diols have the same global formula. It has been proposed that diols originate from di-hydroperoxides reactions [21].

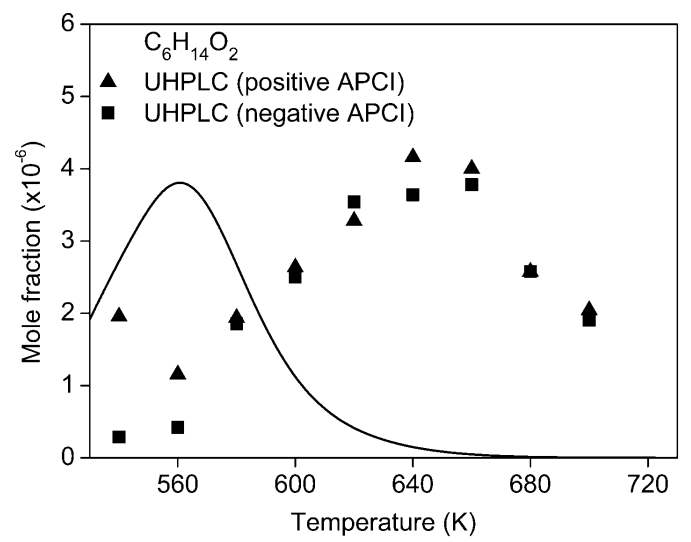

Fig. 4. Comparison of data (symbols: circle positive APCI, triangle negative APCI) and simulations (line) using the model of Wang [14]. The raw data are scaled to simulations using a mechanism proposed earlier [14]. Experimental errors are estimated to be less than $40 \%$, as before $[29,32]$.

Their presence in the products could be verified by observing the formation of products of two H/D exchanges (Table 5). UHPLC/MS analyses using APCI (+/-) modes showed the presence of several chromatographic peaks with very low intensity, of the order of $10^{4}$ (Supplementary Material, Fig. S3). This can be explained by the instability of hydroperoxides. Figure 4 shows the variation as a function of temperature of the integrated $\mathrm{ROOH}$ signal obtained by UHPLC-Orbitrap. Computations using a literature model [14] show a maximum difference of $\sim 100 \mathrm{~K}$ between experimental and computed peak of concentration for $\mathrm{ROOH}$. Rodriguez reported that the discrepancies between modeling and data could be reduced by increasing the activation energy of ROOH decomposition by several $\mathrm{kcal} / \mathrm{mol}$ [48]. More temperature deviations between data and simulations were observed for other products, as presented in the next paragraphs.

$\mathrm{ROOH}$ can undergo $\mathrm{H}$-atom abstraction followed by $\mathrm{O}_{2}$ addition and intramolecular rearrangement reactions and form unsaturated $\mathrm{ROOH}$ or hexenyl hydroperoxides by two different mechanisms (Fig. 5). A signal 
corresponding to $\mathrm{C}_{6} \mathrm{H}_{12} \mathrm{O}_{2}$ species was detected in both positive $\left(\mathrm{C}_{6} \mathrm{H}_{13} \mathrm{O}_{2}{ }^{+}, m / z\right.$ 117.0910) and negative $\left(\mathrm{C}_{6} \mathrm{H}_{11} \mathrm{O}_{2}{ }^{-}\right.$, $m / z$ 115.0764) ionization modes. $\mathrm{C}_{6} \mathrm{H}_{12} \mathrm{O}_{2}$ can also correspond to other molecules, such as hydroxy ketone/aldehyde. Unsaturated $\mathrm{ROOH}$ being less stable than hydroxy ketone/aldehyde molecules, comparison of $\mathrm{C}_{6} \mathrm{H}_{13} \mathrm{O}_{2}{ }^{+}$ chromatograms (Fig. 6) after a period of 7 weeks showed that some chromatographic peaks had decreased in intensity. Thus, the latter may correspond to unsaturated hydroperoxides (Rt 3 to $5 \mathrm{~min}$ ). Stable compounds can correspond to hydroxy ketone/aldehydes. Furthermore, the DNPH derivatization allowed to observe the formation of many $\mathrm{C}_{6} \mathrm{H}_{12} \mathrm{O}_{2}$ dinitrophenyl-hydrazone derivatives (which means the presence of a carbonyl function (Supplementary Material, Fig. S4). The comparison between the different chromatographic peaks of $\mathrm{C}_{6} \mathrm{H}_{12} \mathrm{O}_{2}$ (positive APCI $\mathrm{C}_{6} \mathrm{H}_{13} \mathrm{O}_{2}^{+}$) before derivatization with DNPH and those remaining after derivatization, shows that the peaks which have not diminished (Rt 3 to $5 \mathrm{~min}$ ), represent compounds which do not react not with DNPH, the latter may be unsaturated hydroperoxides. However, the peaks whose intensity has decreased (Rt after 5 min) correspond to molecules having a ketone or aldehyde function which reacts with DNPH (Supplementary Material, Fig. S5).

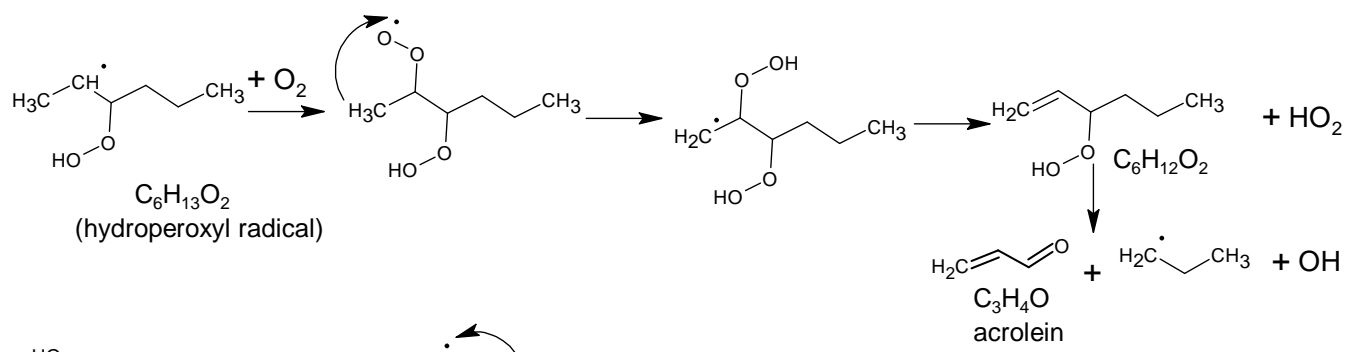

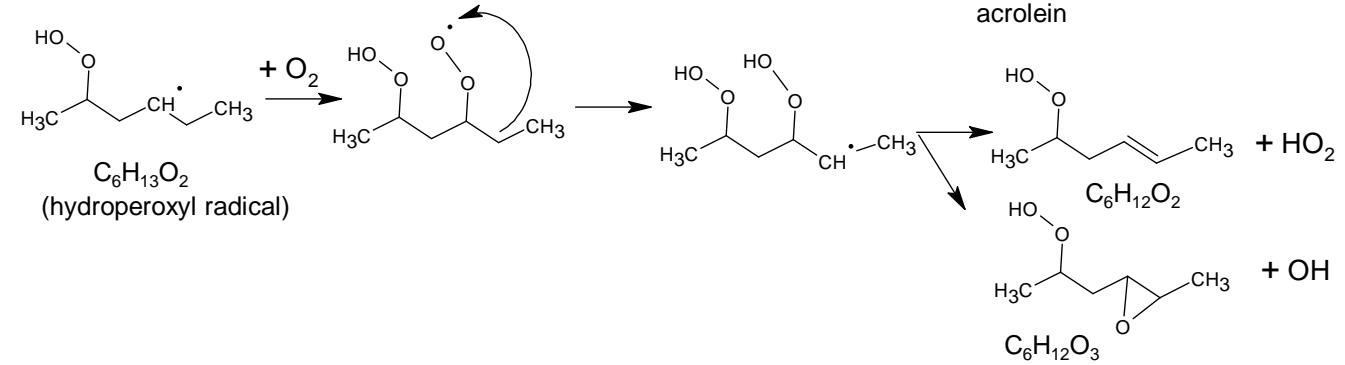

Fig. 5. Formation pathways for hexenyl hydroperoxides during the low temperature oxidation of n-hexane.

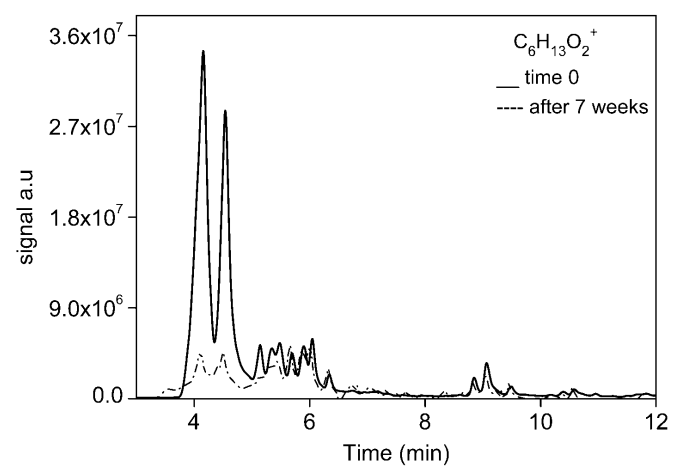

Fig. 6. Chromatograms showing formation of $\mathrm{C}_{6} \mathrm{H}_{12} \mathrm{O}_{2}$. The analyses were performed using a $\mathrm{C}_{18}$ UHPLC-APCI (+) $\left(\mathrm{C}_{6} \mathrm{H}_{13} \mathrm{O}_{2}{ }^{+}, \mathrm{m} / z\right.$ 117.0910). Comparison between analyses carried out shortly after sample collection and after 7 weeks.

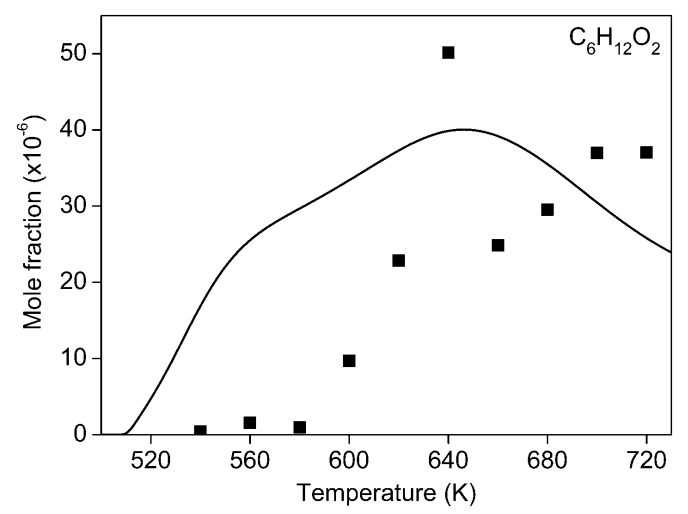

Fig. 7. Comparison of data (Orbitrap data scaled to modeling results, symbols) and modeling (line) of $\mathrm{C}_{6} \mathrm{H}_{12} \mathrm{O}_{2}$ formed during oxidation of $2500 \mathrm{ppm}$ of $\mathrm{n}$-hexane $(\varphi=0.5$, residence time of $1.5 \mathrm{~s}$, and $10 \mathrm{~atm})$. 
Figure 7 shows reasonable agreement between modelling and experimental results, although the production of $\mathrm{C}_{6} \mathrm{H}_{12} \mathrm{O}_{2}$ is overestimated below ca. $640 \mathrm{~K}$. Table 5 summarizes the results obtained for the oxidation of 2500 ppm of n-hexane (See Table 1). The analyses were performed by FIA-HPCI +/-.

Table 5. Products of oxidation of $2500 \mathrm{ppm}$ of $\mathrm{n}$-hexane in a JSR at $600 \mathrm{~K}$ and $10 \mathrm{~atm}$. H/D exchange done by addition of $\mathrm{D}_{2} \mathrm{O}$.

\begin{tabular}{|c|c|c|c|c|c|c|}
\hline \multirow{3}{*}{$\begin{array}{l}\mathrm{M} \\
(\mathrm{g} / \mathrm{mole})\end{array}$} & \multirow{2}{*}{\multicolumn{2}{|c|}{ Compounds }} & \multicolumn{4}{|c|}{ Ionization mode } \\
\hline & & & \multicolumn{2}{|c|}{$\mathrm{APCI}(+)$} & \multicolumn{2}{|l|}{ APCI (-) } \\
\hline & Formula & Name & $\begin{array}{l}m / z \\
{[\mathrm{M}+\mathrm{H}]^{+}}\end{array}$ & $\begin{array}{l}\text { Signal } \\
\text { (a.u) }\end{array}$ & $\begin{array}{l}m / z \\
{[\mathrm{M}-\mathrm{H}]^{-}}\end{array}$ & $\begin{array}{l}\text { Signal } \\
\text { (a.u) }\end{array}$ \\
\hline 56 & $\mathrm{C}_{3} \mathrm{H}_{4} \mathrm{O}$ & Acrolein and isomers & 57.0335 & $1.4 \mathrm{E} 7$ & 55.0232 & $1.5 \mathrm{E} 4$ \\
\hline 60 & $\mathrm{C}_{2} \mathrm{H}_{4} \mathrm{O}_{2}$ & Acetic acid and isomers & 61.0283 & $3.1 \mathrm{E} 5$ & 59.0139 & $1.1 \mathrm{E} 8$ \\
\hline 61 & $\mathrm{C}_{2} \mathrm{H}_{3} \mathrm{D}_{1} \mathrm{O}_{2}$ & Acetic acid-d $\mathrm{d}_{1}$ & 62.0346 & $1.6 \mathrm{E} 5$ & 60.0201 & $7.2 \mathrm{E} 8$ \\
\hline 74 & $\mathrm{C}_{3} \mathrm{H}_{6} \mathrm{O}_{2}$ & Propanoic acid and isomers & 75.0439 & $4.0 \mathrm{E} 5$ & 73.0295 & $5.7 \mathrm{E} 7$ \\
\hline 75 & $\mathrm{C}_{3} \mathrm{H}_{5} \mathrm{D}_{1} \mathrm{O}_{2}$ & Propanoic acid and isomers- $\mathrm{d}_{1}$ & 76.0501 & $4.2 \mathrm{E} 5$ & 74.0358 & 3.7E6 \\
\hline 88 & $\mathrm{C}_{4} \mathrm{H}_{8} \mathrm{O}_{2}$ & Butyric acid and isomers & 89.0594 & $4.1 \mathrm{E} 5$ & 87.0452 & $1.3 \mathrm{E} 7$ \\
\hline 96 & $\mathrm{C}_{6} \mathrm{H}_{8} \mathrm{O}$ & $\begin{array}{l}\text { Keto hexadiene and hydroxy } \\
\text { hexatriene }\end{array}$ & 97.0646 & $3.5 \mathrm{E} 7$ & 95.0503 & $7.0 \mathrm{E} 5$ \\
\hline 97 & $\mathrm{C}_{6} \mathrm{H}_{7} \mathrm{D}_{1} \mathrm{O}$ & hydroxy hexatriene- $\mathrm{d}_{1}$ & 98.0709 & 7.4E6 & - & - \\
\hline 98 & $\mathrm{C}_{6} \mathrm{H}_{10} \mathrm{O}$ & $\begin{array}{l}\text { Keto hexene and hydroxy } \\
\text { hexadiene }\end{array}$ & 99.0802 & $3.2 \mathrm{E} 8$ & 97.0660 & $3.1 \mathrm{E} 5$ \\
\hline 99 & $\mathrm{C}_{6} \mathrm{H}_{9} \mathrm{D}_{1} \mathrm{O}$ & hydroxy hexadiene- $\mathrm{d}_{1}$ & 100.0864 & $1.2 \mathrm{E} 8$ & - & - \\
\hline 100 & $\mathrm{C}_{6} \mathrm{H}_{12} \mathrm{O}$ & $\begin{array}{l}\text { Cyclic ethers, hexanone and } \\
\text { hexanal }\end{array}$ & 101.0958 & $6.7 \mathrm{E} 7$ & 99.0816 & $5.3 \mathrm{E} 3$ \\
\hline 101 & $\mathrm{C}_{6} \mathrm{H}_{11} \mathrm{D}_{1} \mathrm{O}$ & Hexanal-d $_{1}$ & 102.1020 & $3.8 \mathrm{E} 7$ & 100.0877 & $2.6 \mathrm{E} 3$ \\
\hline 114 & $\mathrm{C}_{6} \mathrm{H}_{10} \mathrm{O}_{2}$ & Hexanedione and keto-enols & 115.0753 & $4.6 \mathrm{E} 8$ & 113.0609 & 7.7E7 \\
\hline 115 & $\mathrm{C}_{6} \mathrm{H}_{9} \mathrm{D}_{1} \mathrm{O}_{2}$ & Keto-enols- $\mathrm{d}_{1}$ & 116.0812 & $5.5 \mathrm{E} 8$ & 114.0671 & $1.7 \mathrm{E} 7$ \\
\hline 116 & $\mathrm{C}_{6} \mathrm{H}_{12} \mathrm{O}_{2}$ & $\begin{array}{l}\text { Unsaturated } \mathrm{ROOH}, \text { Hydroxy } \\
\text { ketone/aldehyde and hexanoic } \\
\text { acid }\end{array}$ & 117.0908 & $2.6 \mathrm{E} 7$ & 115.0765 & $9.7 \mathrm{E} 5$ \\
\hline 117 & $\mathrm{C}_{6} \mathrm{H}_{11} \mathrm{D}_{1} \mathrm{O}_{2}$ & Hexanoic acid and isomers- $\mathrm{d}_{1}$ & 118.0968 & $4.6 \mathrm{E} 6$ & 116.0828 & $3.0 \mathrm{E} 4$ \\
\hline 118 & $\mathrm{C}_{6} \mathrm{H}_{14} \mathrm{O}_{2}$ & Diol-ROOH & 119.1063 & $4.6 \mathrm{E} 4$ & 117.0923 & $2.8 \mathrm{E} 3$ \\
\hline 119 & $\mathrm{C}_{6} \mathrm{H}_{13} \mathrm{D}_{1} \mathrm{O}_{2}$ & Diol-ROOH-d ${ }_{1}$ & 120.1126 & $1.0 \mathrm{E} 4$ & - & $\S$ \\
\hline 120 & $\mathrm{C}_{6} \mathrm{H}_{12} \mathrm{D}_{2} \mathrm{O}_{2}$ & Diol- $\mathrm{d}_{2}$ & 121.1188 & $8.0 \mathrm{E} 2$ & - & $\S$ \\
\hline 128 & $\mathrm{C}_{6} \mathrm{H}_{8} \mathrm{O}_{3}$ & Triketones and diketo-enols & 129.0543 & $1.2 \mathrm{E} 7$ & 127.0401 & $3.4 \mathrm{E} 8$ \\
\hline 129 & $\mathrm{C}_{6} \mathrm{H}_{7} \mathrm{D}_{1} \mathrm{O}_{3}$ & diketo-enols- $\mathrm{d}_{1}$ & 130.0606 & $9.5 \mathrm{E} 6$ & 128.0464 & $1.7 \mathrm{E} 8$ \\
\hline 130 & $\mathrm{C}_{6} \mathrm{H}_{10} \mathrm{O}_{3}$ & Unsaturated KHP and keto-acid & 131.0701 & $8.2 \mathrm{E} 6$ & 129.0557 & $1.9 \mathrm{E} 8$ \\
\hline 131 & $\mathrm{C}_{6} \mathrm{H}_{9} \mathrm{D}_{1} \mathrm{O}_{3}$ & $\begin{array}{l}\text { Unsaturated KHP and Keto } \\
{\text { acid- } \mathrm{d}_{1}}\end{array}$ & 132.0762 & $1.1 \mathrm{E} 7$ & 130.0619 & $9.6 \mathrm{E} 7$ \\
\hline 132 & $\mathrm{C}_{6} \mathrm{H}_{12} \mathrm{O}_{3}$ & Keto-hydroperoxide & 133.0856 & $1.3 \mathrm{E} 6$ & 131.0713 & 9.7E7 \\
\hline 133 & $\mathrm{C}_{6} \mathrm{H}_{11} \mathrm{D}_{1} \mathrm{O}_{3}$ & Keto-hydroperoxide- $\mathrm{d}_{1}$ & 134.0918 & $2.5 \mathrm{E} 6$ & 132.0777 & 4.7E7 \\
\hline 142 & $\mathrm{C}_{6} \mathrm{H}_{6} \mathrm{O}_{4}$ & Tetraketone & 143.0336 & $5.6 \mathrm{E} 4$ & 141.0193 & $2.9 \mathrm{E} 7$ \\
\hline 146 & $\mathrm{C}_{6} \mathrm{H}_{10} \mathrm{O}_{4}$ & Diketo-hydroperoxide & 147.0648 & $2.3 \mathrm{E} 6$ & 145.0506 & $8.8 \mathrm{E} 7$ \\
\hline 147 & $\mathrm{C}_{6} \mathrm{H}_{9} \mathrm{D}_{1} \mathrm{O}_{4}$ & Diketo-hydroperoxide- $\mathrm{d}_{1}$ & 148.0711 & $4.1 \mathrm{E} 6$ & 146.0569 & $2.6 \mathrm{E} 7$ \\
\hline 148 & $\mathrm{C}_{6} \mathrm{H}_{12} \mathrm{O}_{4}$ & Hydroxy ketohydroperoxides & 149.0805 & $2.6 \mathrm{E} 4$ & 147.0662 & $2.3 \mathrm{E} 6$ \\
\hline 149 & $\mathrm{C}_{6} \mathrm{H}_{11} \mathrm{D}_{1} \mathrm{O}_{4}$ & Hydroxy ketohydroperoxides- $\mathrm{d}_{1}$ & 150.0868 & $1.1 \mathrm{E} 5$ & 148.0725 & 2.0E6 \\
\hline 150 & $\mathrm{C}_{6} \mathrm{H}_{10} \mathrm{D}_{2} \mathrm{O}_{4}$ & Hydroxy ketohydroperoxides- $\mathrm{d}_{2}$ & 151.0931 & $7.2 \mathrm{E} 4$ & 149.0788 & $3.5 \mathrm{E} 5$ \\
\hline 160 & $\mathrm{C}_{6} \mathrm{H}_{8} \mathrm{O}_{5}$ & Triketo-hydroperoxide & 161.0442 & $3.3 \mathrm{E} 3$ & 159.0299 & $1.2 \mathrm{E} 7$ \\
\hline 161 & $\mathrm{C}_{6} \mathrm{H}_{7} \mathrm{D}_{1} \mathrm{O}_{5}$ & Triketo-hydroperoxide- $\mathrm{d}_{1}$ & - & $\S$ & 160.0362 & $1.4 \mathrm{E} 6$ \\
\hline 164 & $\mathrm{C}_{6} \mathrm{H}_{12} \mathrm{O}_{5}$ & Keto-dihydroperoxides & 165.0767 & $3.9 \mathrm{E} 3$ & 163.0612 & $1.2 \mathrm{E} 6$ \\
\hline 165 & $\mathrm{C}_{6} \mathrm{H}_{11} \mathrm{D}_{1} \mathrm{O}_{5}$ & Keto-dihydroperoxides- $\mathrm{d}_{1}$ & - & $\S$ & 164.0675 & $3.3 \mathrm{E} 5$ \\
\hline 166 & $\mathrm{C}_{6} \mathrm{H}_{10} \mathrm{D}_{2} \mathrm{O}_{5}$ & Keto-dihydroperoxides- $\mathrm{d}_{2}$ & - & - & 165.0740 & $3.2 \mathrm{E} 3$ \\
\hline 178 & $\mathrm{C}_{6} \mathrm{H}_{10} \mathrm{O}_{6}$ & Diketo-dihydroperoxides & - & - & 177.0405 & 4.7E5 \\
\hline 179 & $\mathrm{C}_{6} \mathrm{H}_{9} \mathrm{D}_{1} \mathrm{O}_{6}$ & Diketo-dihydroperoxides- $\mathrm{d}_{1}$ & - & - & 178.0468 & $1.8 \mathrm{E} 5$ \\
\hline 180 & $\mathrm{C}_{6} \mathrm{H}_{8} \mathrm{D}_{2} \mathrm{O}_{6}$ & Diketo-dihydroperoxides- $\mathrm{d}_{2}$ & - & - & 179.0531 & $1.6 \mathrm{E} 4$ \\
\hline 180 & $\mathrm{C}_{6} \mathrm{H}_{12} \mathrm{O}_{6}$ & Hydroxy keto dihydroperoxides & - & - & 179.0561 & $3.1 \mathrm{E} 5$ \\
\hline 181 & $\mathrm{C}_{6} \mathrm{H}_{11} \mathrm{D}_{1} \mathrm{O}_{6}$ & $\begin{array}{l}\text { Hydroxy keto } \\
\text { dihydroperoxides- } \mathrm{d}_{1}\end{array}$ & - & - & 180.0624 & $3.8 \mathrm{E} 5$ \\
\hline
\end{tabular}




\begin{tabular}{|c|c|c|c|c|c|c|}
\hline 182 & $\mathrm{C}_{6} \mathrm{H}_{10} \mathrm{D}_{2} \mathrm{O}_{6}$ & $\begin{array}{l}\text { Hydroxy keto } \\
\text { dihydroperoxides- } \mathrm{d}_{2}\end{array}$ & - & - & 181.0687 & $7.6 \mathrm{E} 4$ \\
\hline 183 & $\mathrm{C}_{6} \mathrm{H}_{9} \mathrm{D}_{3} \mathrm{O}_{6}$ & $\begin{array}{l}\text { Hydroxy keto } \\
\text { dihydroperoxides-d } 3\end{array}$ & - & - & 182.0752 & $5.4 \mathrm{E} 3$ \\
\hline 196 & $\mathrm{C}_{6} \mathrm{H}_{12} \mathrm{O}_{7}$ & Keto-trihydroperoxides & - & - & 195.0511 & $4.9 \mathrm{E} 4$ \\
\hline 197 & $\mathrm{C}_{6} \mathrm{H}_{11} \mathrm{D}_{1} \mathrm{O}_{7}$ & Keto-trihydroperoxides- $\mathrm{d}_{1}$ & - & - & 196.0573 & $7.9 \mathrm{E} 4$ \\
\hline 198 & $\mathrm{C}_{6} \mathrm{H}_{10} \mathrm{D}_{2} \mathrm{O}_{7}$ & Keto-trihydroperoxides- $\mathrm{d}_{2}$ & - & - & 197.0636 & $1.5 \mathrm{E} 4$ \\
\hline 199 & $\mathrm{C}_{6} \mathrm{H}_{9} \mathrm{D}_{3} \mathrm{O}_{7}$ & Keto-trihydroperoxides- $\mathrm{d}_{3}$ & - & - & 198.0698 & $\S$ \\
\hline 210 & $\mathrm{C}_{6} \mathrm{H}_{12} \mathrm{O}_{8}$ & $\begin{array}{l}\text { Hydroxy keto } \\
\text { trihydroperoxides }\end{array}$ & - & - & 211.0459 & $5.2 \mathrm{E} 3$ \\
\hline 211 & $\mathrm{C}_{6} \mathrm{H}_{11} \mathrm{D}_{1} \mathrm{O}_{8}$ & $\begin{array}{l}\text { Hydroxy keto } \\
\text { trihydroperoxides- } \mathrm{d}_{1}\end{array}$ & - & - & 212.0525 & $1.1 \mathrm{E} 4$ \\
\hline 212 & $\mathrm{C}_{6} \mathrm{H}_{10} \mathrm{D}_{2} \mathrm{O}_{8}$ & $\begin{array}{l}\text { Hydroxy keto } \\
\text { trihydroperoxides- } \mathrm{d}_{2}\end{array}$ & - & - & 213.0584 & $\S$ \\
\hline 213 & $\mathrm{C}_{6} \mathrm{H}_{9} \mathrm{D}_{3} \mathrm{O}_{8}$ & $\begin{array}{l}\text { Hydroxy keto } \\
\text { trihydroperoxides- } \mathrm{d}_{3}\end{array}$ & - & - & 214.0647 & $\S$ \\
\hline
\end{tabular}

Note: $\S$ under limit of detection; - Not detected.

$\mathrm{C}_{18}$-UHPLC-MS-APCI (+) analyses of $\mathrm{C}_{6} \mathrm{H}_{12} \mathrm{O}_{3}\left(\mathrm{C}_{6} \mathrm{H}_{13} \mathrm{O}_{3}{ }^{+}, m / z\right.$ 133.0856) showed the presence of several chromatographic peaks that could be KHPs or other chemical species having the same exact mass (Fig. 8a). Gaussian curve fitting algorithm was applied to separate the different contributions of the isomers in order to calculate peaks areas and plotting their different profiles as a function of temperature. Thus, the peaks having the same trend as the KHPs modeling were attributed to KHPs (Fig. 8a, peaks \# 1, 2, 5, 6, 7, 8, and 9). The data were compared to the KHPs modeling profile (Fig. 8b). $\mathrm{C}_{6} \mathrm{H}_{13} \mathrm{O}_{3}{ }^{+}(\mathrm{m} / z$ 133.0856) MS/MS analyses (HCD $10 \mathrm{eV}$ ) produced several fragments, some were identified and confirm the molecular structure of KHPs (Table 6). Some fragments may be common to several KHP isomers. For example: $\mathrm{C}_{6} \mathrm{H}_{11} \mathrm{O}_{2}{ }^{+}\left(\mathrm{m} / z\right.$ 115.0749), $\mathrm{C}_{3} \mathrm{H}_{7} \mathrm{O}^{+}(\mathrm{m} / z$ 59.0490), $\mathrm{C}_{3} \mathrm{H}_{5} \mathrm{O}^{+}\left(\mathrm{m} / z\right.$ 57.0334), and $\mathrm{C}_{2} \mathrm{H}_{5} \mathrm{O}_{2}{ }^{+}\left(\mathrm{m} / z\right.$ 61.0283). However, some fragments $\left(\mathrm{C}_{4} \mathrm{H}_{9} \mathrm{O}, \mathrm{m} / z, 73.0645\right.$ and $\mathrm{C}_{4} \mathrm{H}_{7} \mathrm{O}_{2}$, $\mathrm{m} / z$ 87.0438) could not be used for the identification of KHPs isomers; these could result from intramolecular rearrangements.
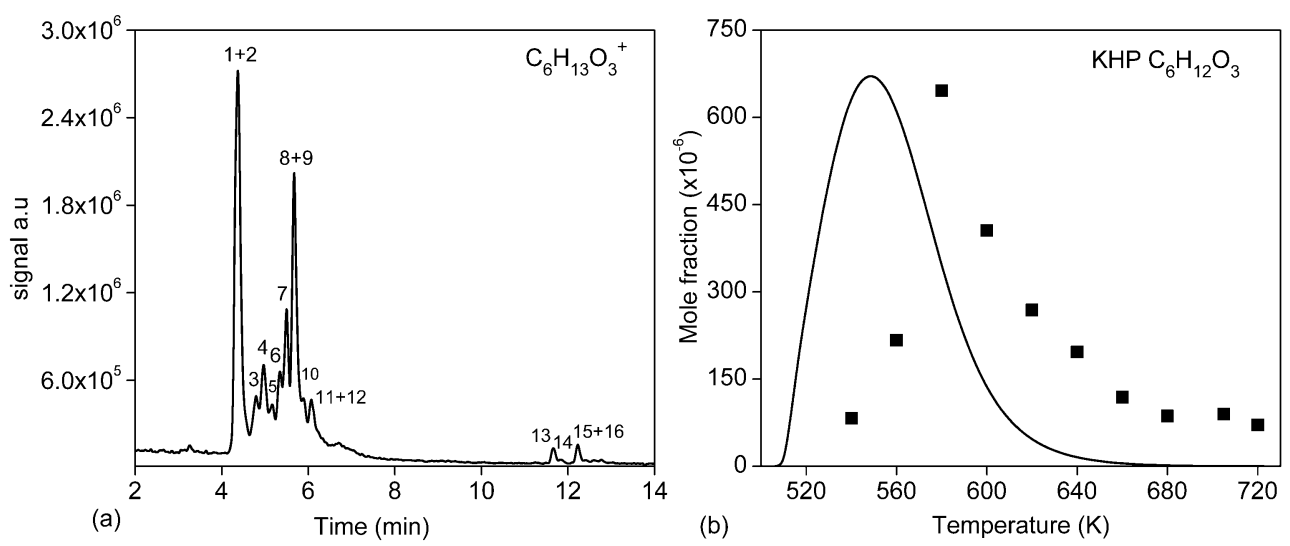

Fig. 8. (a) Chromatographic separation $\mathrm{C}_{6} \mathrm{H}_{12} \mathrm{O}_{3}\left(\mathrm{C}_{6} \mathrm{H}_{13} \mathrm{O}_{3}{ }^{+} \mathrm{m} / 2\right.$ 133.0856) isomers obtained by $\mathrm{n}$-hexane oxidation at $600 \mathrm{~K}$. $\mathrm{C}_{18}$ UHPLC-APCI positive mode was used. (b) Formation of $\mathrm{C}_{6} \mathrm{H}_{12} \mathrm{O}_{3}$ KHPs: comparison of UHPLC data (scaled to modeling results, symbols) and modeling (line) using the model of Wang [14]. The data were obtained by integration of UHPLC-HRMS APCI $(+)$ signal $(\mathrm{m} / \mathrm{z}$ 133.0859) and scaled to the computed maximum concentration. Experimental errors are estimated to be less than 40\%, as earlier [29, 32].

The signal attributed to KHPs abruptly increases below the ceiling temperature. It reaches a maximum at a temperature corresponding to $\sim 60 \%$ conversion of $\mathrm{n}$-hexane $(\sim 590 \mathrm{~K})$. Such matching has been observed earlier in JSR experiments conducted near 1 bar ( $\sim 550 \mathrm{~K}$ [49] and $\sim 530 \mathrm{~K}$ [15]). Figure 8b shows a comparison of the experimental results (positive mode APCI) for the sum of the 7 KHPs and the simulations for n-heptane determined under JSR conditions. This figure shows that the reaction mechanism used here [14] predicts the variation of KHPs concentration as a function of temperature in the cool flame regime, while the computed mole fraction profile is shifted towards lower temperatures in comparison with the data. 
Table 6. Structure of observed fragments in MS/MS analyses (HCD 10eV) of $\mathrm{C}_{6} \mathrm{H}_{12} \mathrm{O}_{3} \mathrm{KHP}$ isomers in APCI positive mode $\left(\mathrm{C}_{6} \mathrm{H}_{13} \mathrm{O}_{3}{ }^{+}, \mathrm{m} / z\right.$ 133.0856).

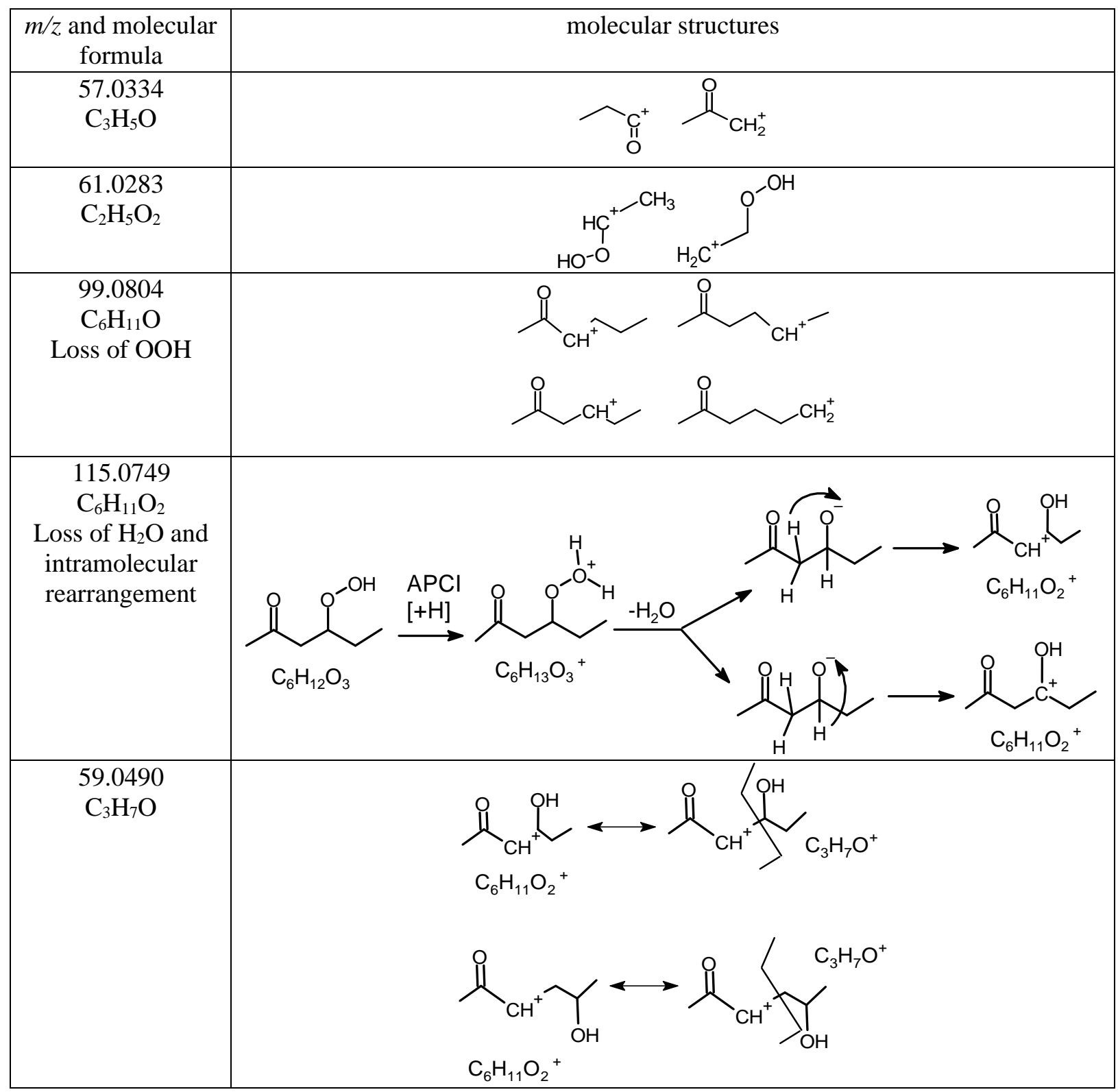

The Korcek mechanism [50] transforms $\gamma$-keto-hydroperoxides into a range of more stable products (ketones/aldehydes and acids). This pathway can modify the global rate of fuel ignition [14]. Computations on $\mathrm{C}_{3}$ $\gamma$-KHPs unimolecular reactions [51] have demonstrated that among 75 possible reactions, the Korcek mechanism had the lowest transition state energy. Several ketones and carboxylic acids can derive from n-hexane's $\gamma$-KHP decomposition, e.g., 2-butanone and acetic acid, acetone and propanoic acid, acetaldehyde and butyric acid (Fig. 9). 


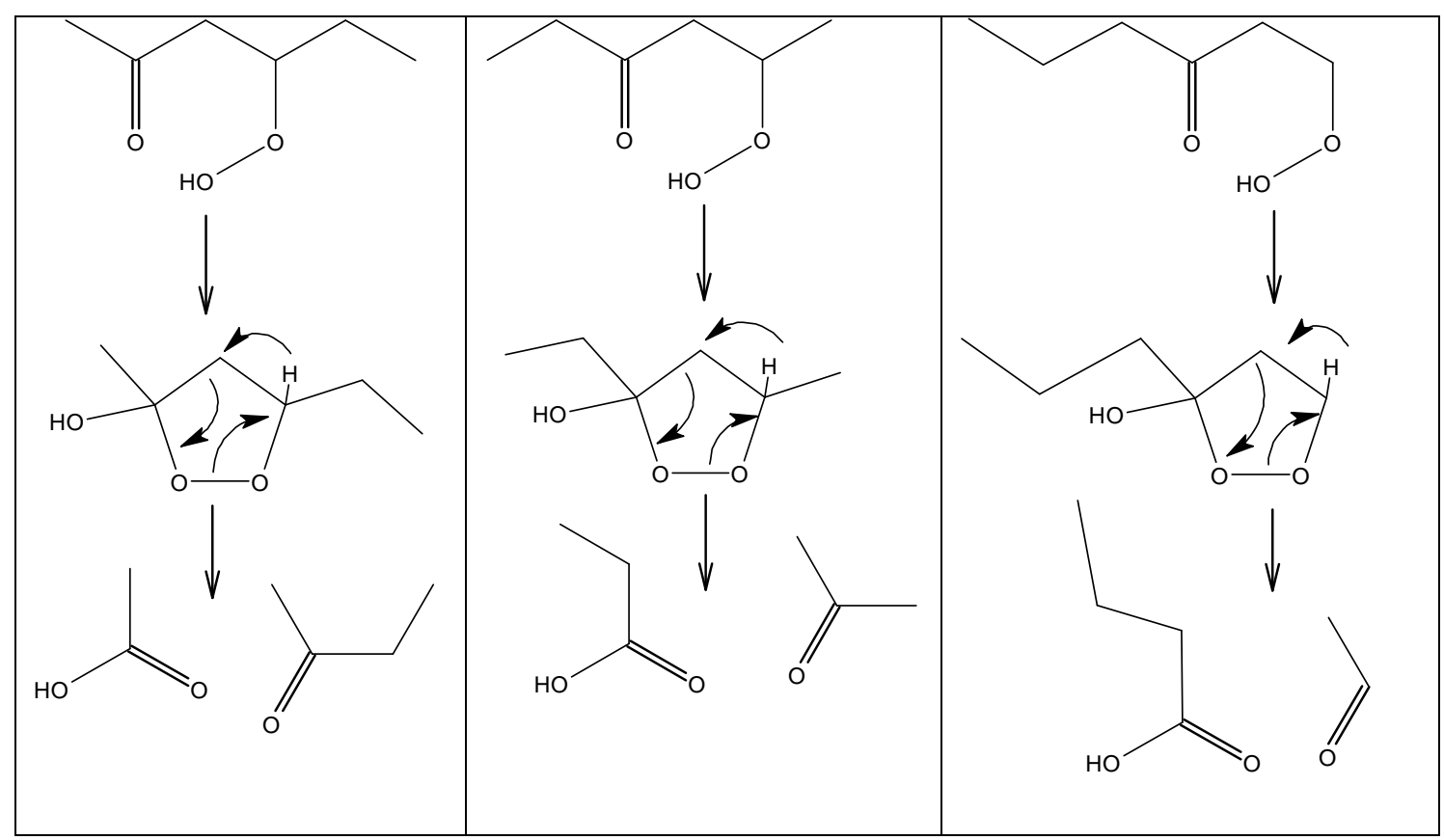

Fig. 9. The Korcek mechanism for most probable n-hexane's $\gamma$-keto-hydroperoxides.

In Fig. 10 we present the formation of ketones/aldehydes and carboxylic acids detected as a function of temperature.

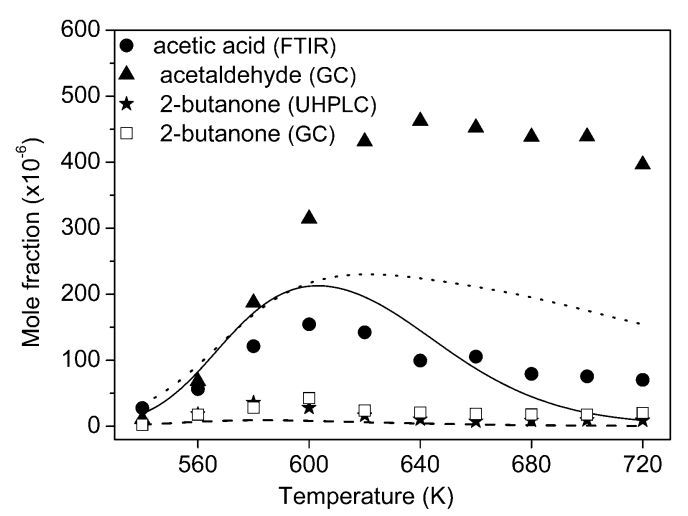

Fig. 10. Acids and ketones potentially produced through the Korcek mechanism during the oxidation of $2500 \mathrm{ppm}$ of n-hexane in a JSR (see Table 1). Data obtained by GC, FTIR and UHPLC (symbols) are compared to modeling results (continuous line: 2-butanone, dotted lined: acetaldehyde, and dashed line: acetic acid). UHPLC-MS analyses were conducted in APCI positive mode and the data were scaled to the corresponding quantitative GC and FTIR data.

Figure 10 presents the concentration profiles for the acid-ketones/aldehyde pairs which could be formed through the Korcek mechanism $\left(\mathrm{C}_{2} \mathrm{H}_{4} \mathrm{O}_{2} / \mathrm{C}_{4} \mathrm{H}_{8} \mathrm{O}, \mathrm{C}_{3} \mathrm{H}_{6} \mathrm{O}_{2} / \mathrm{C}_{3} \mathrm{H}_{6} \mathrm{O}\right.$, and $\left.\mathrm{C}_{4} \mathrm{H}_{8} \mathrm{O}_{2} / \mathrm{C}_{2} \mathrm{H}_{4} \mathrm{O}\right)$. The different analyses (UHPLC Orbitrap, FTIR and GC-MS) did not allow the detection of butyric acid. Propanoic acid and acetone signals were detected in UHPLC Orbitrap (+/-) modes. However, their profiles could not be plotted due to coelution (co-elution of acetone and propionaldehyde). Nevertheless, we could observe that the intensity of DNPHacetone is way less intense than that of DNPH-propionaldehyde (Supplementary Material, Table S2). Therefore, if the formation of acetone occurs via the Korcek route, it should be of minor importance here. The decomposition of the most favorable KHP via the Korcek mechanism, $\mathrm{KHP}^{2,4}$, would yield acetic acid and 2-butanone. These products were observed, with predominance of the acid. If the small production of 2-butanone is attributed to the Korcek mechanism, again, it seems it is of minor importance whereas acetic acid can be produced through other routes. The comparison between modeling and experimental profiles of the species which could be formed through the Korcek mechanism reveals an overestimation of the production of 2-butanone by the kinetic model. Conversely, acetaldehyde and acetic acid concentrations are underpredicted by the model. 
KHPs $\left(\mathrm{C}_{6} \mathrm{H}_{12} \mathrm{O}_{3}\right)$ may react via other reaction pathways. They can form lower mass KHPs $\left(\mathrm{C}_{3} \mathrm{H}_{6} \mathrm{O}_{3}, \mathrm{C}_{4} \mathrm{H}_{8} \mathrm{O}_{3}\right.$ and $\mathrm{C}_{5} \mathrm{H}_{10} \mathrm{O}_{3}$ ) according to the mechanism proposed earlier [14] (Table 7).

Table 7. Formation of $\mathrm{C}_{3} \mathrm{H}_{6} \mathrm{O}_{3}, \mathrm{C}_{4} \mathrm{H}_{8} \mathrm{O}_{3}$ and $\mathrm{C}_{5} \mathrm{H}_{10} \mathrm{O}_{3}$ KHP's isomers formed by decomposition of $\mathrm{C}_{6} \mathrm{H}_{12} \mathrm{O}_{3} \mathrm{KHPs}$ during the oxidation of n-hexane:

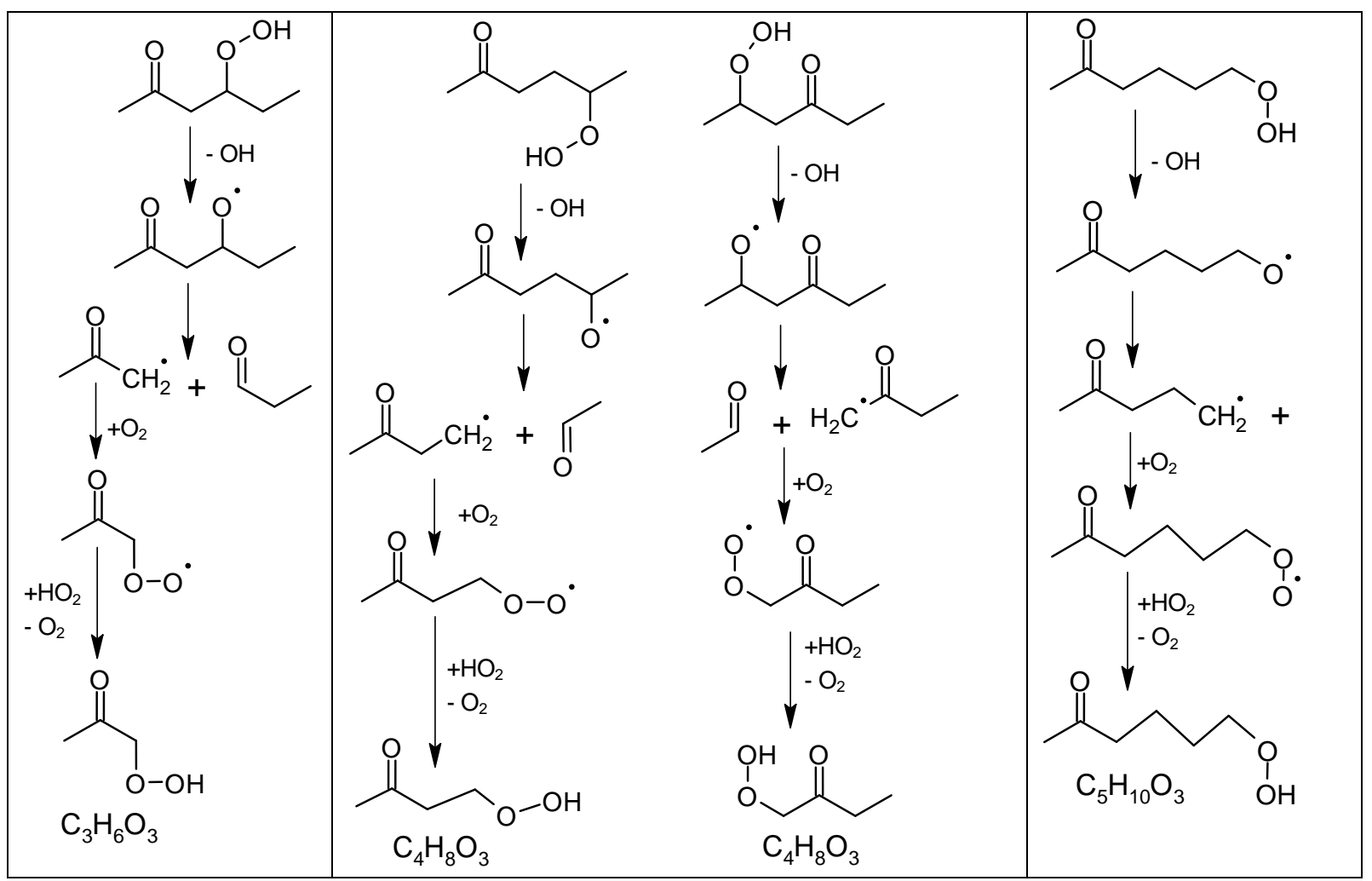

According to the kinetic scheme proposed earlier [14] the formation of three $\mathrm{C}_{3} \mathrm{H}_{6} \mathrm{O}_{3}$, five $\mathrm{C}_{4} \mathrm{H}_{8} \mathrm{O}_{3}$, and ten $\mathrm{C}_{5} \mathrm{H}_{10} \mathrm{O}_{3}$ KHPs occurs in the following order of importance $\mathrm{C}_{3} \mathrm{H}_{6} \mathrm{O}_{3}>>\mathrm{C}_{4} \mathrm{H}_{8} \mathrm{O}_{3}>\mathrm{C}_{5} \mathrm{H}_{10} \mathrm{O}_{3}$. UHPLC-MS APCI (+) analyses revealed chromatographic peaks corresponding to these different KHPs, two peaks for $\mathrm{C}_{3} \mathrm{H}_{6} \mathrm{O}_{3}\left(\mathrm{C}_{3} \mathrm{H}_{7} \mathrm{O}_{3}{ }^{+}\right.$, $\mathrm{m} / \mathrm{z}$ 91.0388), three peaks for $\mathrm{C}_{4} \mathrm{H}_{8} \mathrm{O}_{3}\left(\mathrm{C}_{4} \mathrm{H}_{9} \mathrm{O}_{3}{ }^{+}, \mathrm{m} / \mathrm{z} 105.0545\right)$ and five peaks for $\mathrm{C}_{5} \mathrm{H}_{10} \mathrm{O}_{3}\left(\mathrm{C}_{5} \mathrm{H}_{11} \mathrm{O}_{3}{ }^{+}, \mathrm{m} / \mathrm{z}\right.$ 119.0702). The presence of a ketone function in these products was confirmed by DNPH derivatization (Supplementary Material Table S1). UHPLC-HRMS analyses showed that the concentrations of $\mathrm{C}_{3}, \mathrm{C}_{4}$, and $\mathrm{C}_{5}$ KHPs reach a maximum at $600 \mathrm{~K}$ (Fig. 11).

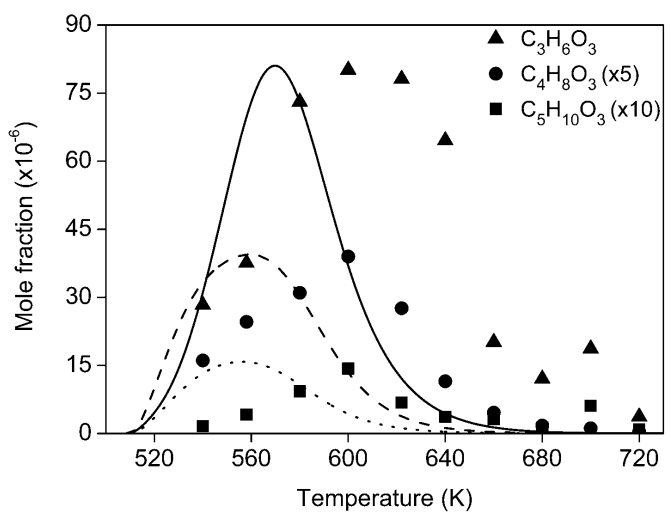

Fig.11. Concentration profiles for $\mathrm{C}_{3}, \mathrm{C}_{4}$, and $\mathrm{C}_{5} \mathrm{KHPs}\left(\mathrm{C}_{3} \mathrm{H}_{7} \mathrm{O}_{3}{ }^{+}, \mathrm{m} / \mathrm{z}\right.$ 91.0388), $\mathrm{C}_{4} \mathrm{H}_{8} \mathrm{O}_{3}\left(\mathrm{C}_{4} \mathrm{H}_{9} \mathrm{O}_{3}{ }^{+}, \mathrm{m} / \mathrm{z} 105.0545\right)$ and $\mathrm{C}_{5} \mathrm{H}_{10} \mathrm{O}_{3}\left(\mathrm{C}_{5} \mathrm{H}_{11} \mathrm{O}_{3}{ }^{+}, \mathrm{m} / \mathrm{z}\right.$ 119.0702). Comparison between UHPLC Orbitrap experimental data scaled to modeling results (symbols) and modeling $\left(\mathrm{C}_{3} \mathrm{H}_{6} \mathrm{O}_{3}\right.$ : continuous line, $\mathrm{C}_{4} \mathrm{H}_{8} \mathrm{O}_{3}$ : dashed line, and $\mathrm{C}_{5} \mathrm{H}_{10} \mathrm{O}_{3}$ : dotted line), respectively.

n-Hexane oxidation at low temperature leads to the formation of other chemical species. Indeed, several aldehydes (formaldehyde, acetaldehyde, acrolein, propionaldehyde, crotonaldehyde, etc.), ketones (2-pentanone, 2-hexanone and 3-hexanone, Methyl vinyl ketone noted MVK) and diones (2.4-pentanedione) were identified by comparison to pure standards or by DNPH derivatization and comparison with DNPHydrazone standards (either if carbonyl 
standard is not available or carbonyl mass is $<50$ uma). Tables S2 and S3 (Supplementary Material) illustrate the identification of the different carbonyl compounds. Examples of comparison of MVK, methyloxirane, 2-pentanone, and 2.4-pentanedione signals variation profiles obtained using UHPLC-HRMS and GC-MS are shown in Fig.12. As for several chemical species mentioned previously, we noticed that there is a difference $(\sim 80 \mathrm{~K})$ between experimental and predicted peak concentration of MVK. The present model predicts the formation of MVK results from the oxidation of 2-butanone (97\%) and 2,3-epoxyhexane (3\%). Formation pathways are given in Scheme 2.
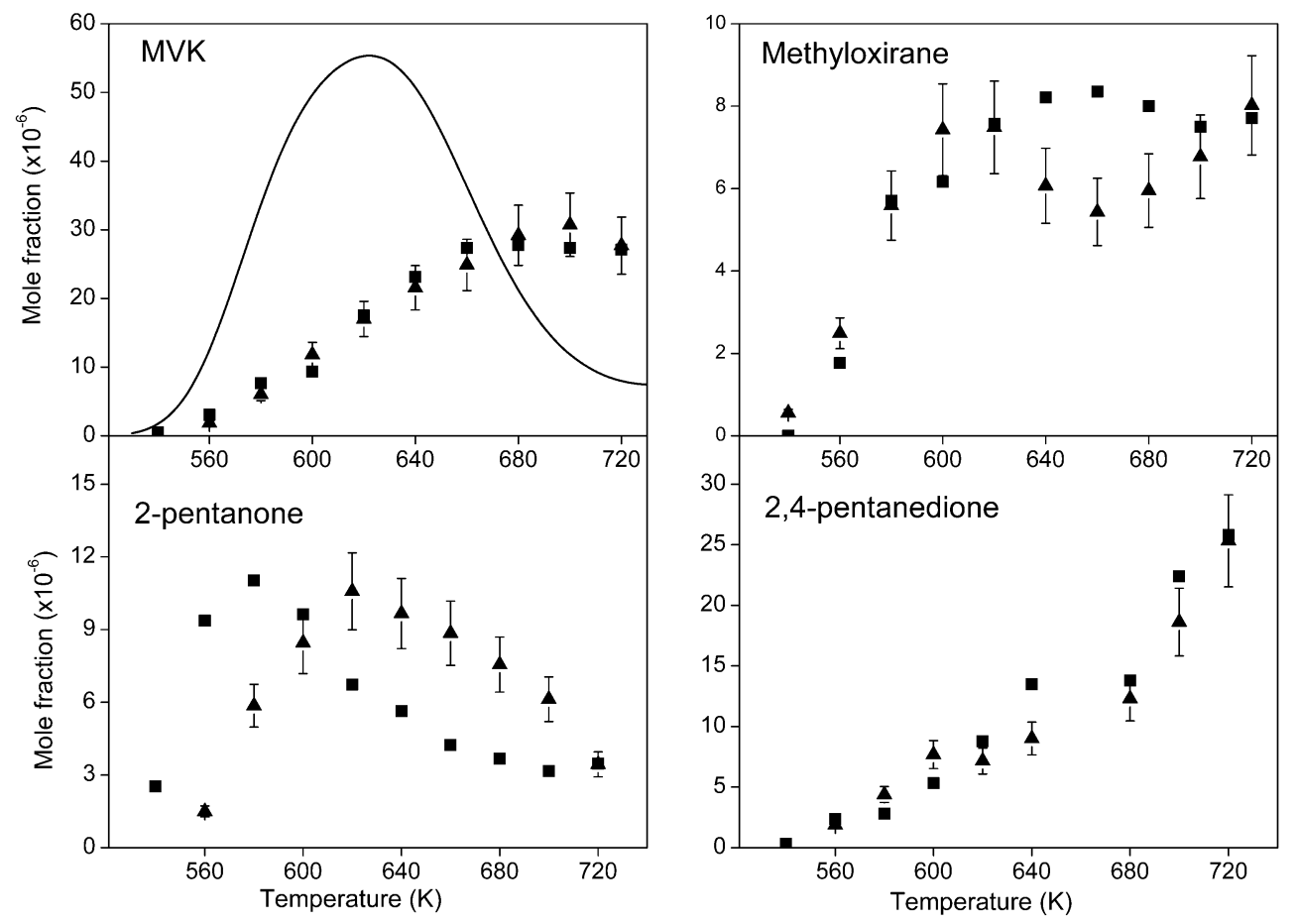

Fig.12. Formation of $\mathrm{MVK}\left(\mathrm{C}_{4} \mathrm{H}_{7} \mathrm{O}^{+}, \mathrm{m} / z\right.$ 71.0491), methyloxirane $\left(\mathrm{C}_{3} \mathrm{H}_{7} \mathrm{O}^{+}, \mathrm{m} / z\right.$ 59.0491), 2-pentanone $\left(\mathrm{C}_{5} \mathrm{H}_{11} \mathrm{O}^{+}, m / z\right.$ 87.0804 $)$ and 2,4-pentanedione $\left(\mathrm{C}_{5} \mathrm{H}_{9} \mathrm{O}_{2}{ }^{+}, \mathrm{m} / z\right.$ 101.0596). Comparison between experimental data (UHPLC-HRMS-APCI+, squares and GC, triangles) and modeling results (line) for MVK.

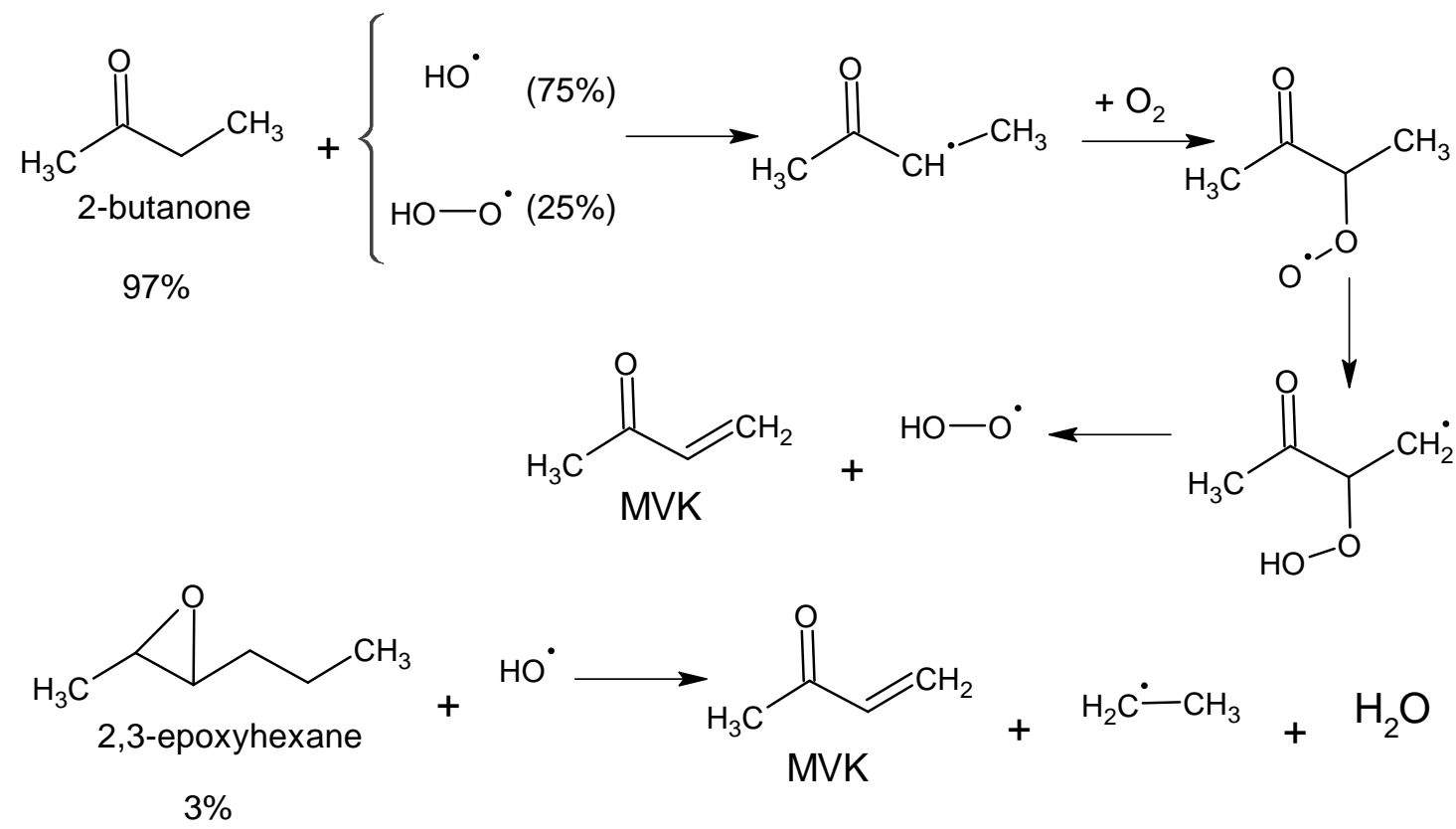

Scheme 2. Formation pathways of MVK during low temperature oxidation of n-hexane.

It has been proposed that diones are produced through the decomposition of KHPs [52], or directly produced by $\mathrm{H}$-atom abstraction on KHPs. [53]: $\mathrm{R}^{\bullet}+\mathrm{C}_{6} \mathrm{H}_{12} \mathrm{O}_{3}{ }^{\mathrm{i}, \mathrm{j}} \rightarrow \mathrm{RH}+\mathrm{C}_{6} \mathrm{H}_{10} \mathrm{O}_{2}{ }^{\mathrm{i}, \mathrm{j}}+\mathrm{OH}^{\bullet}$ 
( $\mathrm{i}$ and $\mathrm{j}$ represent the positions of carbonyl and $\mathrm{OOH}$ groups in KHPs). Roaming reactions of KHPs [54] to produce a dione and water, and ${ }^{\bullet} \mathrm{OOQOOH}$ decomposition [55] have also been proposed to explain diones formation.

Here, several diones were observed as a function of temperature using UHPLC-MS analyses (Fig. 13a). Figures $13 \mathrm{~b}$ and $13 \mathrm{c}$ show the variation of 2,5-hexanedione (Rt $4.17 \mathrm{~min}$ ) and 2,4-hexanedione (Rt $4.35 \mathrm{~min}$ ) signal $\left(\mathrm{C}_{6} \mathrm{H}_{11} \mathrm{O}_{2}{ }^{+} \mathrm{m} / z\right.$ 115.0753). As noticed for several other cool flame products, experimentally, the formation of diones peaks around 580K. UHPLC-MS analyses using negative APCI (Fig. 13a) reveal the presence of other $\mathrm{C}_{6} \mathrm{H}_{10} \mathrm{O}_{2}$ isomeric compounds which can be keto-enols. This possibility was verified by the occurrence of an H/D exchange (Table 5).
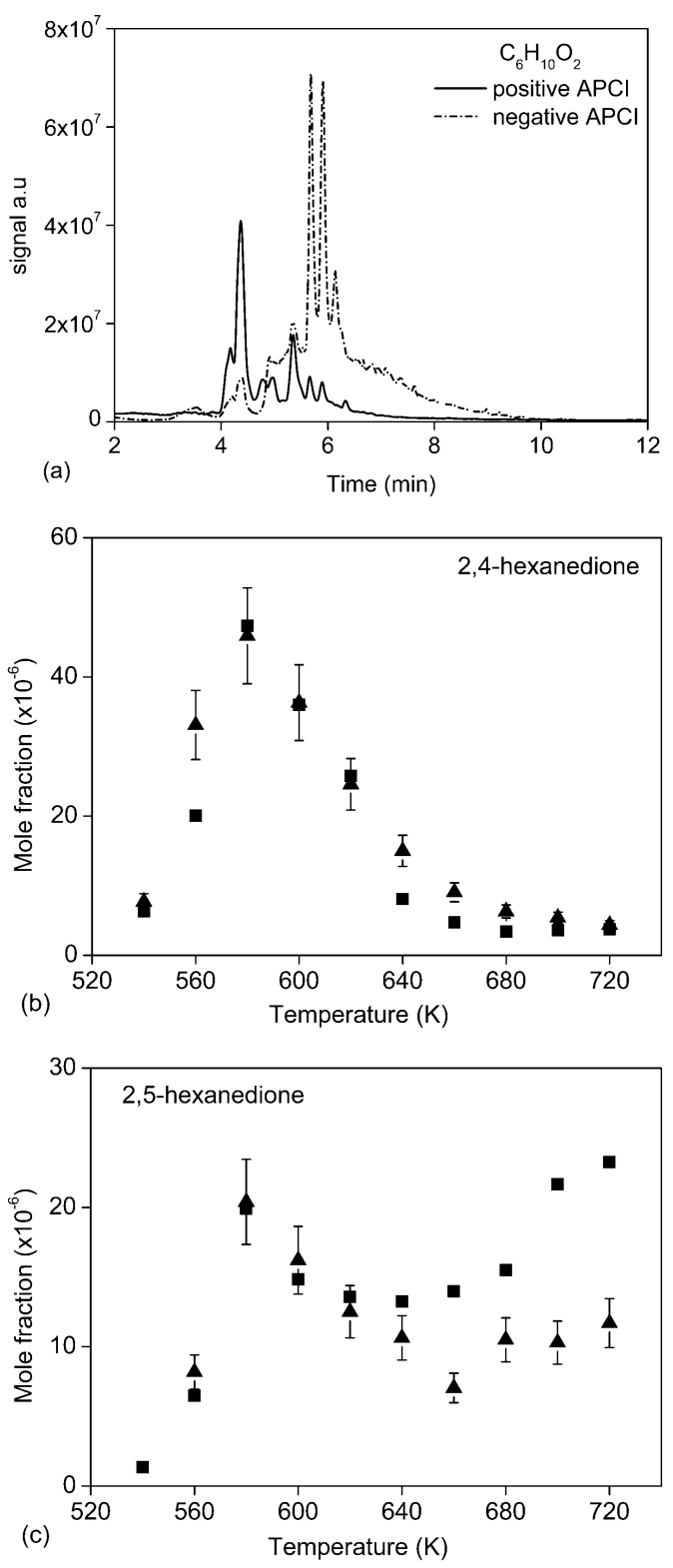

Fig. 13. Diones $\mathrm{C}_{6} \mathrm{H}_{10} \mathrm{O}_{2}$ formation during n-hexane oxidation in a JSR: (a) chromatogram showing $\mathrm{C}_{6} \mathrm{H}_{10} \mathrm{O}_{2}$ using $\mathrm{C}_{18}$ UHPLC-APCI analyses: full line APCI (+) $m / z$ 115.0753, $\mathrm{C}_{6} \mathrm{H}_{11} \mathrm{O}_{2}{ }^{+}$, dotted line APCI (-) $m / z$ 113.0609, $\mathrm{C}_{6} \mathrm{H}_{9} \mathrm{O}_{2}{ }^{-}$ . (b) profile of 2,4-hexanedione, (c) profile of 2,5-hexanedione obtained by UHPLC-HRMS (square), GC-MS (triangle) analyses. HRMS data are scaled to the corresponding quantitative GC data.

During n-hexane oxidation, several cyclic ethers can be produced in the NTC region. They are formed by decomposition of alkyl hydroperoxides: $\mathrm{QOOH} \rightarrow$ cyclic ether $+\mathrm{OH}$.

UHPLC-MS signal corresponding to $\mathrm{C}_{6} \mathrm{H}_{12} \mathrm{O}$ isomers was detected in APCI +/- $\left(\mathrm{m} / z\right.$ 101.0960, $\left.\mathrm{C}_{6} \mathrm{H}_{13} \mathrm{O}^{+}\right)$and $\left(\mathrm{m} / z\right.$ 99.0816 $\left.\mathrm{C}_{6} \mathrm{H}_{11} \mathrm{O}^{-}\right)$, see Fig. 14a. The cyclic ethers profiles obtained by UHPLC-MS analysis were compared to the modeling and to total signal of 2,5-dimethyl-THF and 2-butyloxirane obtained by GC-MS (Fig. 14b). 

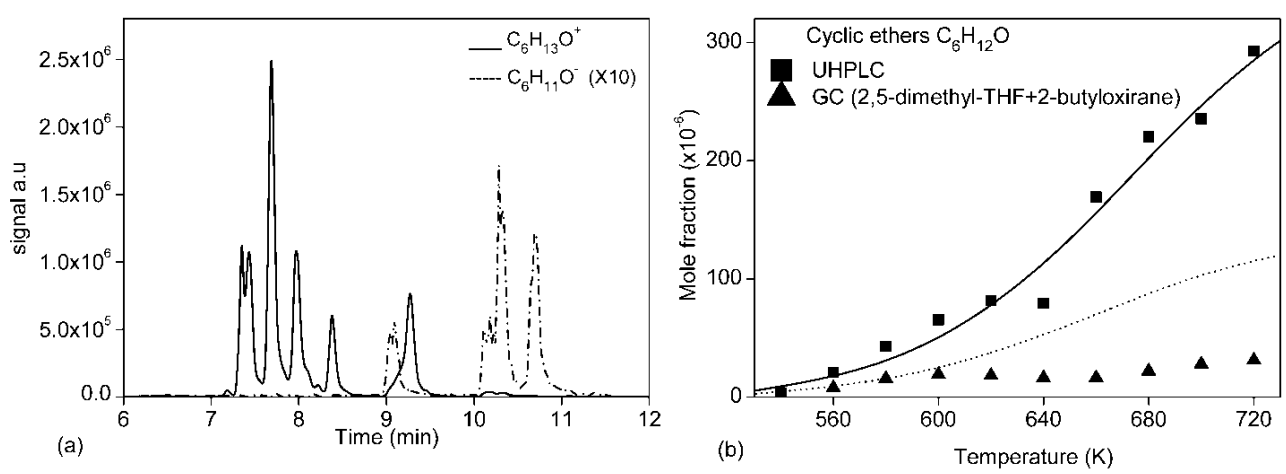

Fig. 14. Cyclic ethers' formation during n-hexane oxidation in a JSR. (a) Chromatograms for $\mathrm{C}_{6} \mathrm{H}_{12} \mathrm{O}$ showing different isomers formed at $720 \mathrm{~K}: 2.5$-dimethyl-THF trans \& cis (Rt 7.67 and $7.97 \mathrm{~min}$ ), 2-butyloxirane (10.13 $\mathrm{min})$, 2-hexanone (9.02 $\mathrm{min})$, 3-hexanone (9.26 min) and hexanal (10.64 min). Analyses were conducted in APCI (+/-) modes $\left.\mathrm{C}_{6} \mathrm{H}_{13} \mathrm{O}^{+}\right), \mathrm{m} / z, 101.0960$ and $\mathrm{C}_{6} \mathrm{H}_{11} \mathrm{O}^{-}, \mathrm{m} / z$ 99.0816. (b) Comparison between experimental signal (symbols): UHPLC (data scaled to modeling results, cyclic ethers integrated signal) and GC (2,5-dimethyl-THF and 2-butyloxirane) compared to modeling results: total cyclic ethers (line), and sum of 2.5 dimethyl-THF and 2butyloxirane (dash).

$\mathrm{C}_{6} \mathrm{H}_{12} \mathrm{O}$ can also correspond to hexanone and hexanal. These molecules have been identified using standards. UHPLC-MS and GC-MS analyses allowed observing the variation of their concentrations during the cool-flame oxidation of n-hexane over the temperature range 540 to $720 \mathrm{~K}$ (Fig. 15).
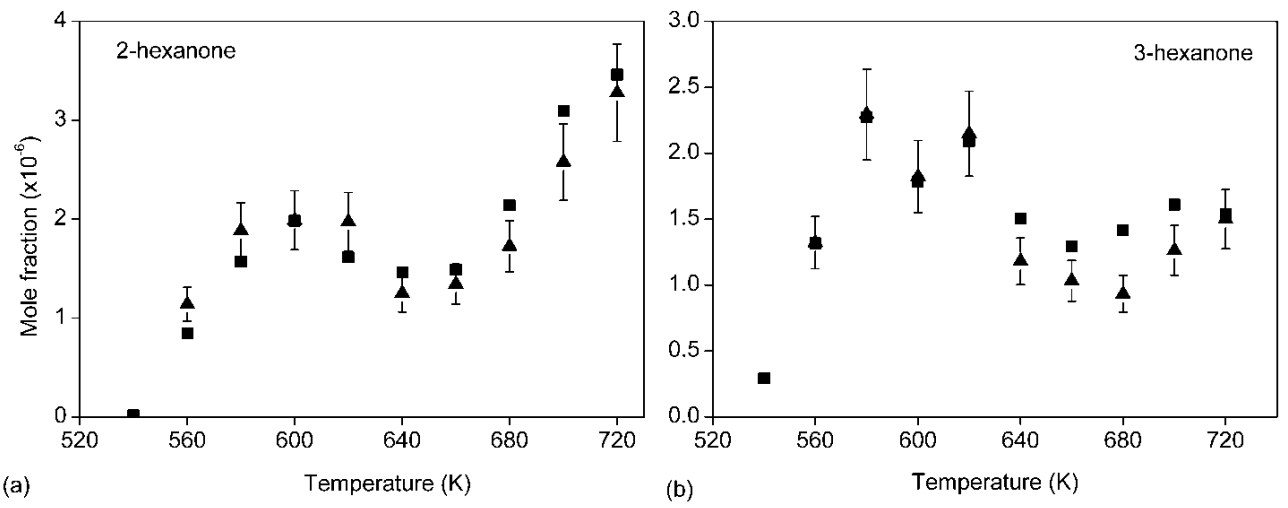

Fig. 15. Formation of (a) 2-hexanone and (b) 3-hexanone during the oxidation of $2500 \mathrm{ppm}$ of $\mathrm{n}$-hexane in a JSR. UHPLC APCI (+) mode $\left(\mathrm{m} / z\right.$ 101.0960, $\left.\mathrm{C}_{6} \mathrm{H}_{13} \mathrm{O}^{+}\right)$(square symbols, scaled to quantitative GC data) compared to GC-MS analyses (triangle symbols).

Figure 15 shows that 2-hexanone and 3-hexanone have two formation phases, which implies two different chemical pathways over the low temperature oxidation of $n$-hexane. The first 2-hexanone formation peaks at a temperature around $600 \mathrm{~K}$. The MS signal decreases between 620 and $640 \mathrm{~K}$ and then increases again between 640 and $720 \mathrm{~K}$. The 3-hexanone MS signal behaves similarly.

Thanks to the use FIA and UHPLC APCI (+/-), different hexenones were detected. For instance, keto hexene $\mathrm{C}_{6} \mathrm{H}_{10} \mathrm{O}\left(\mathrm{C}_{6} \mathrm{H}_{11} \mathrm{O}^{+} \mathrm{m} / z\right.$ 99.0802, $\mathrm{C}_{6} \mathrm{H}_{9} \mathrm{O}^{-} \mathrm{m} / z$ 97.0660) (Fig.16a and b) and keto hexadiene $\mathrm{C}_{6} \mathrm{H}_{8} \mathrm{O}\left(\mathrm{C}_{6} \mathrm{H}_{9} \mathrm{O}^{+}, \mathrm{m} / z\right.$ 97.0646; $\mathrm{C}_{6} \mathrm{H}_{7} \mathrm{O}^{-}, \mathrm{m} / z$ 95.0503), see Fig. 17a and b. The presence of a carbonyl group has been confirmed by DNPH derivatization (Supplementary Material, Table S1). However, the comparison of $\mathrm{C}_{6} \mathrm{H}_{10} \mathrm{O}$ (Fig. 16b) and $\mathrm{C}_{6} \mathrm{H}_{8} \mathrm{O}$ (Fig.17b) chromatographic peaks before and after DNPH derivatization show a decrease of only some peaks corresponding to isomers with a carbonyl function $\left(\mathrm{C}_{6} \mathrm{H}_{10} \mathrm{O}\right.$ keto hexene and $\mathrm{C}_{6} \mathrm{H}_{8} \mathrm{O}$ keto hexadiene), which indicates that the other peaks (not reacting with DNPH) correspond to different $\mathrm{C}_{6} \mathrm{H}_{10} \mathrm{O}$ and $\mathrm{C}_{6} \mathrm{H}_{8} \mathrm{O}$ isomers. For example, the presence of hydroxy hexadiene, $\mathrm{C}_{6} \mathrm{H}_{10} \mathrm{O}$, and hydroxy hexatriene, $\mathrm{C}_{6} \mathrm{H}_{8} \mathrm{O}$, could be responsible for the observed H/D exchange reported in Table 5. 

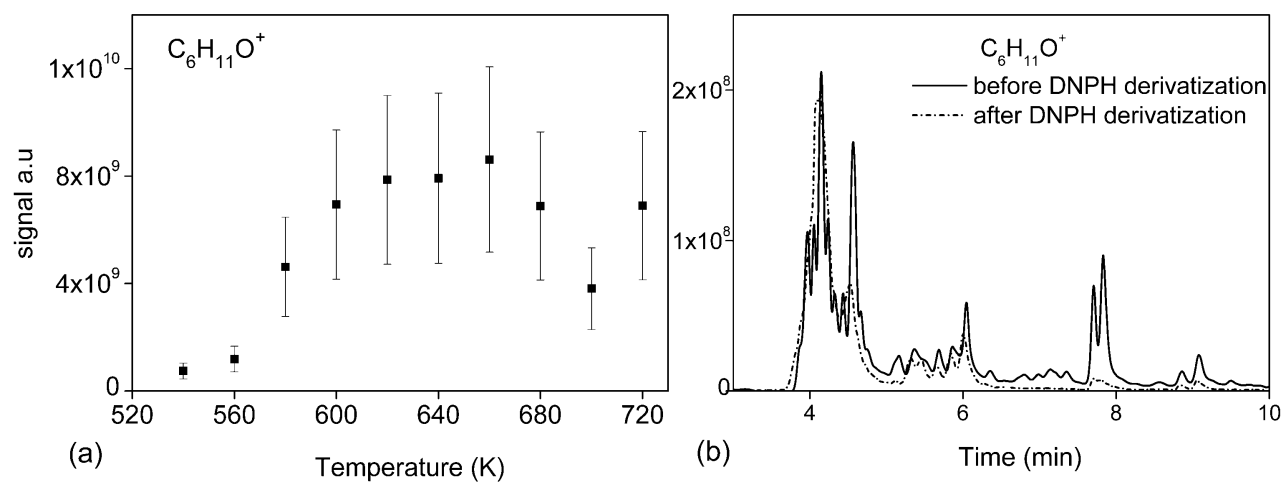

Fig. 16. Formation of $\mathrm{C}_{6} \mathrm{H}_{10} \mathrm{O}$ during $n$-hexane oxidation. (a) Variation of keto hexene as a function of JSR temperature. (b) Chromatographic peaks showing variation of the $\mathrm{C}_{6} \mathrm{H}_{10} \mathrm{O}$ signal $\left(\mathrm{C}_{6} \mathrm{H}_{11} \mathrm{O}^{+}, \mathrm{m} / z\right.$ 99.0802) before and after DNPH derivatization. Keto hexenes correspond to peaks with decreasing intensity after DNPH derivatization.

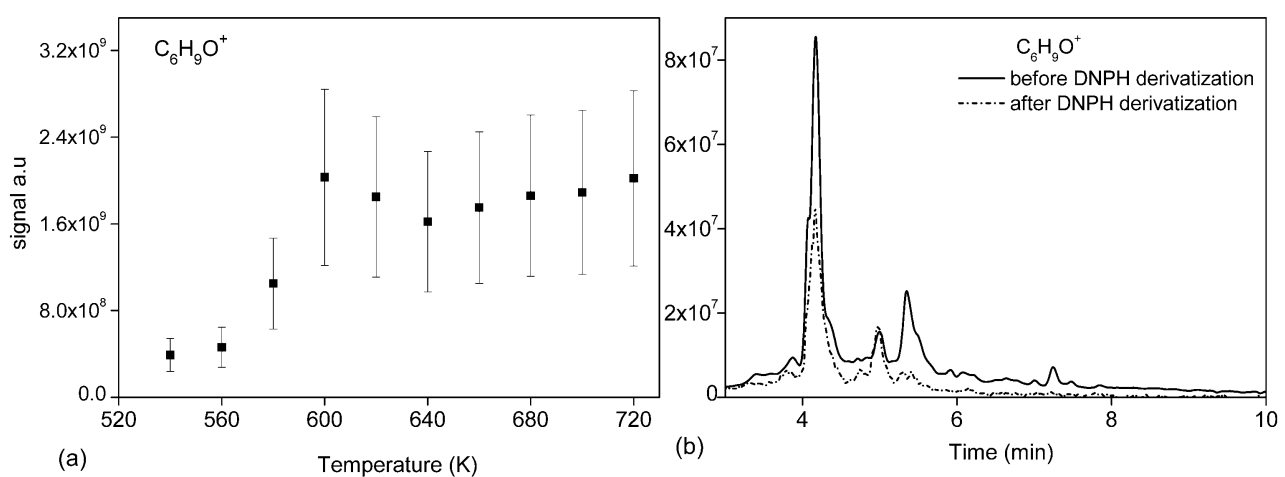

Fig. 17. Formation of $\mathrm{C}_{6} \mathrm{H}_{8} \mathrm{O}$ during n-hexane oxidation. (a) Variation of keto hexadiene as function as JSR temperature. (b) Chromatographic peaks showing variation of $\mathrm{C}_{6} \mathrm{H}_{8} \mathrm{O}$ concentrations $\left(\mathrm{C}_{6} \mathrm{H}_{9} \mathrm{O}^{+} \mathrm{m} / z\right.$ 97.0646) before and after DNPH derivatization. Keto hexadienes correspond to peaks with decreasing intensity after DNPH derivatization.

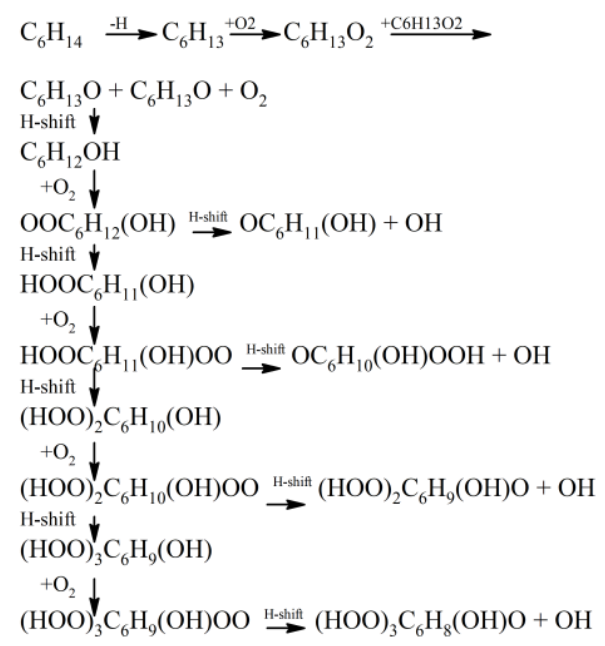

Scheme 3. Peroxy radicals' oxidation pathways commonly considered in atmospheric chemistry, ultimately yielding HOMs.

Other oxidation pathways for peroxy radicals can occur. Scheme 3 presents one of them which proceeds via the formation of alkoxy radicals which react via sequential $\mathrm{H}$-shifts and $\mathrm{O}_{2}$ additions. The products of this reaction pathway consisting of $\mathrm{C}_{6} \mathrm{H}_{12} \mathrm{O}_{2,4,6,8}$ were observed in the present experiments (Table 5). In addition to all the chemical species reported in this paper, other highly oxygenated molecules have been detected, such as $\mathrm{C}_{6} \mathrm{H}_{10} \mathrm{O}_{3}$ (unsaturated KHPs and keto acids, MW 130), $\mathrm{C}_{6} \mathrm{H}_{8} \mathrm{O}_{3}$ (triketone and diketo-enols, MW 128), $\mathrm{C}_{6} \mathrm{H}_{8} \mathrm{O}_{5}$ (Triketo hydroperoxides, MW 160), as well as the other formula listed in Table 5. 


\section{Conclusion and Perspectives}

n-Hexane oxidation was conducted in a JSR at $10 \mathrm{~atm}$ and an equivalence ratio of 0.5 (540-720 K, residence time of $1.5 \mathrm{~s}$ and initial fuel concentration of $2500 \mathrm{ppm}$; 530-800 K, residence time of $0.7 \mathrm{~s}$ and $1000 \mathrm{ppm}$ of fuel). Cool-flame products formed in JSR experiments were characterized after collection of samples dissolved in cooled acetonitrile. These liquid samples were analyzed using several analytical techniques (FIA and UHPLC analyses coupled with high resolution mass spectrometry using APCI in both positive and negative modes). All of these analyses allowed characterizing hydroperoxides $\left(\mathrm{C}_{6} \mathrm{H}_{14} \mathrm{O}_{2}\right)$, unsaturated hydroperoxides $\left(\mathrm{C}_{6} \mathrm{H}_{12} \mathrm{O}_{2}\right)$, ketohydroperoxides $\left(\mathrm{C}_{6} \mathrm{H}_{12} \mathrm{O}_{3}\right)$, ketohydroperoxides $\left(\mathrm{C}_{3} \mathrm{H}_{6} \mathrm{O}_{3}, \mathrm{C}_{4} \mathrm{H}_{8} \mathrm{O}_{3}, \mathrm{C}_{5} \mathrm{H}_{10} \mathrm{O}_{3}\right)$ resulting from decomposition of KHPs $\mathrm{C}_{6} \mathrm{H}_{12} \mathrm{O}_{3}$, diones $\left(\mathrm{C}_{6} \mathrm{H}_{10} \mathrm{O}_{2}\right)$, Cyclic ethers and $\mathrm{C}_{6}$-ketones $\left(\mathrm{C}_{6} \mathrm{H}_{12} \mathrm{O}\right)$. Also, highly oxygenated molecules were detected $\left(\mathrm{C}_{6} \mathrm{H}_{12} \mathrm{O}_{4-8}\right)$. Carbonyl compounds were characterized by DNPH derivatization. To verify the presence of hydroxyl or hydroperoxyl groups in n-hexane oxidized products, $\mathrm{H} / \mathrm{D}$ exchange with $\mathrm{D}_{2} \mathrm{O}$ was used. MS-MS analyses were used to try to identify the KHPs isomers.

Additional experiments using complementary techniques are planned to better assess the reaction pathways of n-hexane oxidation in cool flames, e.g., JSR-MS-ToF-synchrotron photoionization, sampling in piston engines. Also, the characterization of HOMs using recently developed strategies [42] are currently applied to a range of fuels, including $n$-hexane. These studies are expected to further confirm similitudes in terms of products of oxidation formed in combustion and in the troposphere.

\section{Acknowledgements}

The authors gratefully acknowledge funding from the Labex Caprysses (convention ANR-11-LABX-0006-01) and from the Région Centre Val de Loire, EFRD, and CPER (projects PROMESTOCK and APROPOR-E).

\section{References}

[1] P. Dagaut; M. Cathonnet, The ignition, oxidation, and combustion of kerosene: A review of experimental and kinetic modeling, Prog. Energy Combust. Sci. 32 (1) (2006) 48-92.

[2] W. J. Pitz; C. J. Mueller, Recent progress in the development of diesel surrogate fuels, Prog. Energy Combust. Sci. 37 (3) (2011) 330-350.

[3] P. Dagaut, On the kinetics of hydrocarbons oxidation from natural gas to kerosene and diesel fuel, Phys. Chem. Chem. Phys. 4 (11) (2002) 2079-2094.

[4] C. Bayındırlı; M. Celik; M. Demiralp; İ. Ors, Investigation Of Effect Of n-Hexane Additives In Biodiesel On Combustion And Exhaust Emissions In Diesel Engines, International Journal of Automotive Engineering and Technologies 6 (3) (2017) 140-147.

[5] M. Çelik; C. Bayindirli, Enhancement performance and exhaust emissions of rapeseed methyl ester by using n-hexadecane and n-hexane fuel additives, Energy 202 (2020) 117643.

[6] C. Bayindirli; M. Celik, Investigation of combustion and emission characteristics of n-hexane and n-hexadecane additives in diesel fuel, Journal of Mechanical Science and Technology 33 (4) (2019) 1937-1946.

[7] A. Burcat; E. Olchanski; C. Sokolinski., Isr. J. Chem. 36 (1996) 313-320.

[8] V.P. Zhukov; V. A. Sechenov; A. Y. Starikovskii, Ignition delay times in lean n-hexane-air mixture at high pressures, Combust. Flame 136 (2004) 257-259.

[9] R. Mevel; K. Chatelain; P. A. Boettcher; G. Dayma; J. E. Shepherd, Low temperature oxidation of n-hexane in a flow reactor, Fuel 126 (2014) 282-293.

[10] Z. Wang; O. Herbinet; Z. Cheng; B. Husson; R. Fournet; F. Qi; F. Battin-Leclerc, Experimental Investigation of the Low Temperature Oxidation of the Five Isomers of Hexane, J. Phys. Chem. A 118 (2014) 5573-5594.

[11] F. Qi, Combustion chemistry probed by synchrotron VUV photoionization mass spectrometry, Proc. Combust. Inst. 34 (2013) 33-63.

[12] K. W. Zhang; C. Banyon; C. Togbe; P. Dagaut; J. Bugler; H. J. Curran, An experimental and kinetic modeling study of nhexane oxidation, Combust. Flame 162 (11) (2015) 4194-4207.

[13] K. W. Zhang; C. Banyon; U. Burke; G. Kukkadapu; S. W. Wagnon; M. Mehl; H. J. Curran; C. K. Westbrook; W. J. Pitz, An experimental and kinetic modeling study of the oxidation of hexane isomers: Developing consistent reaction rate rules for alkanes, Combust. Flame 206 (2019) 123-137.

[14] Z. D. Wang; S. M. Sarathy, Third O-2 addition reactions promote the low-temperature auto-ignition of n-alkanes, Combust. Flame 165 (2016) 364-372.

[15] Z. D. Wang; B. J. Chen; K. Moshammer; D. M. Popolan-Vaida; S. Sioud; V. S. B. Shankar; D. Vuilleumier; T. Tao; L. Ruwe; E. Brauer; N. Hansen; P. Dagaut; K. Kohse-Hoinghaus; M. A. Raji; S. M. Sarathy, n-Heptane cool flame chemistry: Unraveling intermediate species measured in a stirred reactor and motored engine, Combust. Flame 187 (2018) 199-216.

[16] O. Perrin; A. Heiss; K. Sahetchian; L. Kerhoas; J. Einhorn, Determination of the isomerization rate constant $\mathrm{HOCH} 2 \mathrm{CH} 2 \mathrm{CH} 2 \mathrm{CH}(\mathrm{OO}$ center dot $) \mathrm{CH} 3->(\mathrm{HOCHCH} 2 \mathrm{CH} 2 \mathrm{CH})-\mathrm{H}$-center $\operatorname{dot}(\mathrm{OOH}) \mathrm{CH} 3$. Importance of intramolecular hydroperoxy isomerization in tropospheric chemistry, Int. J. Chem. Kinet. 30 (12) (1998) 875-887. 
[17] N. Blin-Simiand; F. Jorand; K. Keller; M. Fiderer; K. Sahetchian, Ketohydroperoxides and ignition delay in internal combustion engines, Combust. Flame 112 (1998) 278-282.

[18] A. Heiss; K. Sahetchian, Isomerization reactions of the n-C4H9O and n-OOC4H8OH radicals in oxygen, Int. J. Chem. Kinet. 28 (7) (1996) 531-544.

[19] K. Sahetchian; J. C. Champoussin; M. Brun; N. Levy; N. Blin-Simiand; C. Aligrot; F. Jorand; M. Socoliuc; A. Heiss; N. Guerassi, Experimental study and modeling of dodecane ignition in a diesel engine, Combust. Flame 103 (3) (1995) $207-220$. [20] M. Zinbo; R. K. Jensen; S. Korcek, Gas-liquid-chromatography of oxygenated compounds related to autoxidation of nhexadecane, Anal. Lett. 10 (2) (1977) 119-132.

[21] R. K. Jensen; S. Korcek; L. R. Mahoney; M. Zinbo, Liquid-phase autoxidation of organic-compounds at elevatedtemperatures .1. stirred flow reactor technique and analysis of primary products from normal-hexadecane autoxidation at 120degrees-C 180-degrees-C, J. Am. Chem. Soc. 101 (25) (1979) 7574-7584.

[22] R. K. Jensen; S. Korcek; L. R. Mahoney; M. Zinbo, Liquid-phase autoxidation of organic-compounds at elevatedtemperatures .2. Kinetics and mechanisms of the formation of cleavage products in normal-hexadecane autoxidation, J. Am. Chem. Soc. 103 (7) (1981) 1742-1749.

[23] R. K. Jensen; M. Zinbo; S. Korcek, HPLC determination of hydroperoxidic products formed in the autoxidation of normalhexadecane at elevated-temperatures, J. Chromatogr. Sci. 21 (9) (1983) 394-397.

[24] R. K. Jensen; S. Korcek; M. Zinbo, Formation, isomerization, and cyclization reactions of hydroperoxyalkyl radicals in hexadecane autoxidation at 160-190-degrees-C, J. Am. Chem. Soc. 114 (20) (1992) 7742-7748.

[25] K. Moshammer; A. W. Jasper; D. M. Popolan-Vaida; Z. D. Wang; V. S. B. Shankar; L. Ruwe; C. A. Taatjes; P. Dagaut; N. Hansen, Quantification of the Keto-Hydroperoxide (HOOCH2OCHO) and Other Elusive Intermediates during LowTemperature Oxidation of Dimethyl Ether, J. Phys. Chem. A 120 (40) (2016) 7890-7901.

[26] Z. Wang; L. Zhang; K. Moshammer; D. M. Popolan-Vaida; V. S. B. Shankar; A. Lucassen; C. Hemken; C. A. Taatjes; S. R. Leone; K. Kohse-Hoeinghaus; N. Hansen; P. Dagaut; S. M. Sarathy, Additional chain-branching pathways in the lowtemperature oxidation of branched alkanes, Combust. Flame 164 (2016) 386-396.

[27] Z. Wang; S. Y. Mohamed; L. Zhang; K. Moshammer; D. M. Popolan-Vaida; V. S. B. Shankar; A. Lucassen; L. Ruwe; N. Hansen; P. Dagaut; S. M. Sarathy, New insights into the low-temperature oxidation of 2-methylhexane, Proc. Combust. Inst. 36 (1) (2017) 373-382.

[28] Z. Wang; D. M. Popolan-Vaida; B. Chen; K. Moshammer; S. Y. Mohamed; H. Wang; S. Sioud; M. A. Raji; K. KohseHöinghaus; N. Hansen; P. Dagaut; S. R. Leone; S. M. Sarathy, Unraveling the structure and chemical mechanisms of highly oxygenated intermediates in oxidation of organic compounds, Proceedings of the National Academy of Sciences 114 (50) (2017) 13102-13107.

[29] N. Belhadj; R. Benoit; P. Dagaut; M. Lailliau; Z. Serinyel; G. Dayma; F. Khaled; B. Moreau; F. Foucher, Oxidation of di-n-butyl ether: Experimental characterization of low-temperature products in JSR and RCM, Combust. Flame 222 (2020) 133-144.

[30] Z. D. Wang; N. Hansen; A. W. Jasper; B. J. Chen; D. M. Popolan-Vaida; K. K. Yalamanchi; A. Najjar; P. Dagaut; S. M. Sarathy, Cool flame chemistry of diesel surrogate compounds: n-Decane, 2-methylnonane, 2,7-dimethyloctane, and nbutylcyclohexane, Combust. Flame 219 (2020) 384-392.

[31] N. Belhadj; R. Benoit; P. Dagaut; M. Lailliau, Experimental characterization of n-heptane low-temperature oxidation products including keto-hydroperoxides and highly oxygenated organic molecules (HOMs), Combust. Flame (2021) https://doi.org/10.1016/j.combustflame.2020.10.021.

[32] N. Belhadj; R. Benoit; P. Dagaut; M. Lailliau; Z. Serinyel; G. Dayma, Oxidation of di-n-propyl ether: Characterization of low-temperature products, Proc. Combust. Inst. 38 (1) (2021) 337-344.

[33] N. Belhadj; R. Benoit; P. Dagaut; M. Lailliau, Experimental characterization of n-heptane low-temperature oxidation products including keto-hydroperoxides and highly oxygenated organic molecules (HOMs), Combust. Flame 224 (2021) 83 93.

[34] N. Belhadj; R. Benoit; P. Dagaut; M. Lailliau, Experimental Characterization of Tetrahydrofuran Low-Temperature Oxidation Products Including Ketohydroperoxides and Highly Oxygenated Molecules, Energy Fuels 10.1021/acs.energyfuels.0c03291 (2021)

[35] F. Bianchi; T. Kurtén; M. Riva; C. Mohr; M. P. Rissanen; P. Roldin; T. Berndt; J. D. Crounse; P. O. Wennberg; T. F. Mentel; J. Wildt; H. Junninen; T. Jokinen; M. Kulmala; D. R. Worsnop; J. A. Thornton; N. Donahue; H. G. Kjaergaard; M. Ehn, Highly Oxygenated Organic Molecules (HOM) from Gas-Phase Autoxidation Involving Peroxy Radicals: A Key Contributor to Atmospheric Aerosol, Chemical Reviews 119 (6) (2019) 3472-3509.

[36] P. Dagaut; N. Belhadj; R. Benoit; G. Dayma; M. Lailliau; Z. Serinyel, in: MCS11 11th Mediterranean Combustion Symposium https://hal.archives-ouvertes.fr/hal-02137413, Tenerife, Spain, 2019.

[37] P. Dagaut; M. Cathonnet; J. P. Rouan; R. Foulatier; A. Quilgars; J. C. Boettner; F. Gaillard; H. James, A Jet-Stirred Reactor for Kinetic-Studies of Homogeneous Gas-Phase Reactions at Pressures up to 10-Atmospheres ( 1 MPa), Journal of Physics E-Scientific Instruments 19 (3) (1986) 207-209.

[38] A. El Bakali; P. Dagaut; L. Pillier; P. Desgroux; J. F. Pauwels; A. Rida; P. Meunier, Experimental and modeling study of the oxidation of natural gas in a premixed flame, shock tube, and jet-stirred reactor, Combust. Flame 137 (1-2) (2004) 109128.

[39] T. Le Cong; P. Dagaut, Experimental and Detailed Modeling Study of the Effect of Water Vapor on the Kinetics of Combustion of Hydrogen and Natural Gas, Impact on NOx, Energy Fuels 23 (1) (2009) 725-734. 
[40] A. Ristori; P. Dagaut; M. Cathonnet, The oxidation of n-hexadecane: Experimental and detailed kinetic modeling, Combust. Flame 125 (3) (2001) 1128-1137.

[41] S. Thion; C. Togbe; Z. Serinyel; G. Dayma; P. Dagaut, A chemical kinetic study of the oxidation of dibutyl-ether in a jetstirred reactor, Combust. Flame 185 (2017) 4-15.

[42] R. Benoit; N. Belhadj; M. Lailliau; P. Dagaut, On the similarities and differences between the products of oxidation of hydrocarbons under simulated atmospheric conditions and cool-flames, Atmos. Chem. Phys. Discuss. 2020 (2020) https://doi.org/10.5194/acp-2020-1070.

[43] N. Belhadj; R. Benoit; P. Dagaut; M. Lailliau, Experimental Characterization of Tetrahydrofuran Low-Temperature Oxidation Products Including Ketohydroperoxides and Highly Oxygenated Molecules, Energy Fuels 35 (9) (2021) $7242-7252$. [44] N. Belhadj; R. Benoit; P. Dagaut; M. Lailliau; B. Moreau; F. Foucher, Low-temperature oxidation of a gasoline surrogate: Experimental investigation in JSR and RCM using high-resolution mass spectrometry, Combust. Flame 228 (2021) $128-141$. [45] R. Benoit; N. Belhadj; M. Lailliau; P. Dagaut, On the similarities and differences between the products of oxidation of hydrocarbons under simulated atmospheric conditions and cool flames, Atmos. Chem. Phys. 21 (10) (2021) 7845-7862.

[46] P. Glarborg; R. J. Kee; J. F. Grcar; J. A. Miller in: PSR: A FORTRAN program for modeling well-stirred reactors., SAND86-8209, Sandia National Laboratories, Livermore, CA, 1986

[47] R. J. Kee; F. M. Rupley; J. A. Miller in: CHEMKIN-II: A Fortran Chemical Kinetics Package for the Analysis of GasPhase Chemical Kinetics., SAND89-8009, Sandia National Laboratories, Livermore, CA, 1989

[48] A. Rodriguez. Combustion study of organic compounds by coupling a jet-stirred reactor with spectroscopic and spectrometric analytical methods : application to the detection of hydroperoxides. Étude de la combustion de composés organiques grâce au couplage d'un réacteur parfaitement agité avec des méthodes analytiques spectroscopiques et spectrométriques : application à la détection des hydroperoxydes. Ph.D. Thesis, Université de Lorraine, Nancy, France, 2016. [49] O. Herbinet; B. Husson; Z. Serinyel; M. Cord; V. Warth; R. Fournet; P. A. Glaude; B. Sirjean; F. Battin-Leclerc; Z. D. Wang; M. F. Xie; Z. J. Cheng; F. Qi, Experimental and modeling investigation of the low-temperature oxidation of n-heptane, Combust. Flame 159 (12) (2012) 3455-3471.

[50] A. Jalan; I. M. Alecu; R. Meana-Paneda; J. Aguilera-Iparraguirre; K. R. Yang; S. S. Merchant; D. G. Truhlar; W. H. Green, New Pathways for Formation of Acids and Carbonyl Products in Low-Temperature Oxidation: The Korcek Decomposition of gamma-Ketohydroperoxides, J. Am. Chem. Soc. 135 (30) (2013) 11100-11114.

[51] C. A. Grambow; A. Jamal; Y. P. Li; W. H. Green; J. Zador; Y. V. Suleimanov, Unimolecular Reaction Pathways of a gamma-Ketohydroperoxide from Combined Application of Automated Reaction Discovery Methods, J. Am. Chem. Soc. 140 (3) (2018) 1035-1048.

[52] N. Blin-Simiand; F. Jorand; K. Sahetchian; M. Brun; L. Kerhoas; C. Malosse; J. Einhorn, Hydroperoxides with zero, one, two or more carbonyl groups formed during the oxidation of n-dodecane, Combust. Flame 126 (1) (2001) $1524-1532$.

[53] M. Pelucchi; M. Bissoli; C. Cavallotti; A. Cuoci; T. Faravelli; A. Frassoldati; E. Ranzi; A. Stagni, Improved Kinetic Model of the Low-Temperature Oxidation of n-Heptane, Energy Fuels 28 (11) (2014) 7178-7193.

[54] R. H. West; C. F. Goldsmith, The impact of roaming radicals on the combustion properties of transportation fuels, Combust. Flame 194 (2018) 387-395.

[55] A. J. Eskola; I. O. Antonov; L. Sheps; J. D. Savee; D. L. Osborn; C. A. Taatjes, Time-resolved measurements of product formation in the low-temperature $(550-675 \mathrm{~K})$ oxidation of neopentane: a probe to investigate chain-branching mechanism, Phys. Chem. Chem. Phys. 21 (2017) 13731-13745. 